NBER WORKING PAPER SERIES

\title{
COMPARATIVE ADVANTAGE AND HETEROGENEOUS FIRMS
}

\author{
Andrew B. Bernard \\ Stephen Redding \\ Peter K. Schott \\ Working Paper 10668 \\ http://www.nber.org/papers/w10668
}

\author{
NATIONAL BUREAU OF ECONOMIC RESEARCH \\ 1050 Massachusetts Avenue \\ Cambridge, MA 02138
}

August 2004

Bernard and Schott gratefully acknowledge research support from the National Science Foundation (SES0241474). Redding gratefully acknowledges financial support from a Philip Leverhulme Prize. We would like to thank Pol Antras, Richard Baldwin, James Harrigan, Marc Melitz, Tony Venables, seminar and conference participants at the NBER Spring Meetings, CEPR, the IMF, Hitotsubashi, Princeton, Columbia, the NY Fed and London School of Economics for helpful comments. The views expressed and any errors are the authors' responsibility. The views expressed herein are those of the author(s) and not necessarily those of the National Bureau of Economic Research.

(C2004 by Andrew B. Bernard, Stephen Redding, and Peter K. Schott. All rights reserved. Short sections of text, not to exceed two paragraphs, may be quoted without explicit permission provided that full credit, including $(\mathbb{C}$ notice, is given to the source. 
Comparative Advantage and Heterogeneous Firms

Andrew B. Bernard, Stephen Redding, and Peter K. Schott

NBER Working Paper No. 10668

August 2004

JEL No. F11, F12, L11

\section{ABSTRACT}

This paper presents a model of international trade that features heterogeneous firms, relative endowment differences across countries, and consumer taste for variety. The paper demonstrates that firm reactions to trade liberalization generate endogenous Ricardian productivity responses at the industry level that magnify countries' comparative advantage. Focusing on the wide range of firmlevel reactions to falling trade costs, the model also shows that, as trade costs fall, firms in comparative advantage industries are more likely to export, that relative firm size and the relative number of firms increases more in comparative advantage industries and that job turnover is higher in comparative advantage industries than in comparative disadvantage industries.

Andrew Bernard

Tuck School of Business

Dartmouth College

100 Tuck Hall

Hanover, NH 03755

and NBER

andrew.b.bernard@dartmouth.edu

Stephen Redding

London School of Economics

Houghton Street

London

WC2A 2AE

United Kingdom

s.j.redding@1se.ac.uk

Peter K. Schott

Yale School of Management

135 Prospect Street

New Haven, CT 06520

and NBER

peter.schott@yale.edu 


\section{Introduction}

This paper adds firm heterogeneity to a model of international trade that features both relative endowment differences across countries and consumer taste for variety. The resulting model outlines the role that country and industry characteristics play in mediating firm-level responses to trade liberalization, and describes how these responses affect aggregate variables such as job turnover, relative wages and average industry productivity. It demonstrates that the actions of heterogeneous firms magnify countries' comparative advantage, creating an additional source of welfare gains from trade. It also generates a wide range of new implications for the response of firms to trade liberalization.

Our approach unites two strands of the international trade literature. The first, synthesized in Helpman and Krugman (1985), integrates the factor proportions framework of the Heckscher-Ohlin model with new trade theory assumptions about imperfect competition and scale economies. The second, exemplified by Bernard, Eaton, Jensen and Kortum (2003) and Melitz (2003), adds trade costs and firms that vary in terms of their productivity to single-factor, single-industry models of intra-industry trade. In this paper we extend both literatures to a more general setting populated by heterogeneous firms, multiple factors of production and asymmetric industries and countries.

Our framework simultaneously explains why some countries export more in certain industries than in others (endowment-driven comparative advantage); why nonetheless twoway trade is observed within industries (firm-level horizontal product differentiation combined with increasing returns to scale); and why, within industries engaged in these two forms of trade, some firms export and others do not (self-selection driven by trade costs). These outcomes, as well as the assumptions underlying the model, are consistent with a host of stylized facts about firms and trade that have emerged across several empirical literatures. $^{1}$

The model allows us to focus on within-industry responses to trade liberalization, including changes in the number and size of firms, entry and exit, the productivity range

\footnotetext{
${ }^{1}$ Taken together, these facts document substantial variation in productivity across firms, frequent firm entry and exit, positive covariation in entry and exit rates across industries, higher productivity among exporting firms, large numbers of non-exporting firms in net export sectors, no feedback from exporting to firm productivity, and substantial sunk costs of entry into export markets. See, among others, Bartelsman and Doms (2000), Bernard and Jensen (1995, 1999, 2004), Clerides, Lach and Tybout (1998), Davis and Haltiwanger (1991), Dunne, Roberts and Samuelson (1989), and Roberts and Tybout (1997a). For recent empirical evidence of Heckscher-Ohlin forces operating at the level of individual firms and products within industries, see Bernard, Jensen and Schott (2004) and Schott (2004).
} 
of producing firms, and the share of firms that export. We examine how these responses vary across industries as countries transition from autarky to both free and costly trade. Costly trade equilibria provide the more novel - and realistic - results, as they capture the asymmetric impact of firm self-selection into export markets on comparative advantage and comparative disadvantage industries.

As in other endowment-driven trade models, transition to both free and costly trade in this paper induces countries to specialize according to comparative advantage. We demonstrate that all four of the major theorems of the Heckscher-Ohlin model - HeckscherOhlin, Stolper-Samuelson, Rybczynski, Factor Price Equalization - continue to apply, with slight modifications to account for firm heterogeneity, monopolistic competition and scale economies. As trade costs fall, factors reallocate across industries, goods prices and factor rewards converge across countries, and the relative wages of abundant factors rise.

Under free trade, consumer taste for variety guarantees that all firms with productivity high enough to overcome the sunk cost of entry become exporters. When trade entails paying both fixed and variable costs, export status, like successful entry, is contingent on firm productivity. Firms drawing a low productivity subsequent to entry are unable to justify the costs of exporting and therefore serve only the domestic market. Firms that draw a high productivity earn sufficient profits net of trade costs to serve both the domestic and foreign markets, i.e. to self-select into the export market.

The central results of the paper arise from the interaction of firm heterogeneity, industry input intensity and country factor abundance during trade liberalization. This interaction results in differential outcomes across firms within industries, across industries within countries, and across countries within industries. We find that industry productivity, the probability of exporting, firm size, and job churning all rise faster in countries' comparative advantage sectors as economies transition from autarky to costly trade.

Trade liberalization raises the average productivity of all industries by forcing a reallocation of economic activity away from lower-productivity firms and towards higherproductivity firms. However, comparative advantage industries experience the greatest increases in productivity as trade costs fall, an outcome which magnifies countries' preexisting comparative advantage by further reducing average costs. This magnification of comparative advantage is driven by the existence of a competitive fringe of firms: when countries liberalize, and export opportunities rise, increased entry by the fringe drives down profits, forces low-productivity firms to exit and thereby raises the average productivity of the industry. Since export opportunities are greater in comparative advantage industries, 
the resulting endogenous Ricardian productivity responses are higher in those industries than in comparative disadvantage industries even though there are no differences in technology across countries within an industry.

The magnification of comparative advantage by heterogenous firms identifies a new source of welfare gains from trade. In existing theoretical work, these gains accrue from reallocating factors to their most productive use across industries, from providing consumers access to a broader range of product varieties than is available domestically, and from aggregate industry productivity increases due to self-selection. Here, the greater productivity gains in comparative advantage industries enhance cross-country differences in opportunity costs of production and therefore provide a further source of welfare gains from trade. These extra increases in productivity also keep the real reward of scarce factors from falling as far during trade liberalization as they do in the standard Heckscher-Ohlin model. As a result, magnification of comparative advantage, like an increase in varieties, mitigates an important distributional implication of the traditional Stolper-Sameulson Theorem.

By expanding access to foreign markets, trade liberalization also raises the probability that firms become exporters. Because export opportunities are more attractive in countries' comparative advantage industries, export probabilities increase more for firms in comparative advantage industries than comparative disadvantage industries.

A number of additional predictions about firm and industry responses to trade liberalization also emerge from the model. In particular, we find that comparative advantage industries experience greater entry and exit and larger increases in firm size than comparative disadvantage industries. The intra-industry disparity between winning, expanding firms (large exporters) and losing, shrinking firms (small non-exporters) rises relatively more in industries of comparative advantage. Similarly, because firm entry and expansion are associated with job creation, and firm exit and decline with job destruction, these outcomes imply relatively greater job turnover in comparative advantage industries as countries liberalize. These results highlight the existence of both winners and losers from liberalization both within and across industries.

The remainder of the paper is structured as follows. Section 2 develops the model and solves for general equilibrium under free trade. Section 3 explores the properties of the free trade equilibrium, highlighting new results on firm and industry changes in response to trade liberalization and discusses the applicability of standard Heckscher-Ohlin theorems. Section 4 introduces fixed and variable trade costs to the model and Section 5 examines the properties of the costly trade equilibrium. Section 6 presents numerical solutions to 
the model to reinforce the intuitions of the analytical results and illustrate the effects of liberalization on job turnover. Section 7 concludes.

\section{Free Trade}

We consider a world of two countries, two industries, two factors and a continuum of heterogeneous firms. We make the standard Heckscher-Ohlin assumption that countries are identical in terms of preferences and technologies, but differ in terms of factor endowments. Factors of production can move between industries within countries but cannot move across countries. We use $H$ to index the skill-abundant home country and $F$ to index the skill-scarce foreign country, so that $\bar{S}^{H} / \bar{L}^{H}>\bar{S}^{F} / \bar{L}^{F}$ where the bars indicate country endowments. Throughout this section we maintain the assumption that international trade is costless.

\subsection{Consumption}

The representative consumer's utility depends on consumption of the output of two industries $(i)$, each of which contains a large number of differentiated varieties $(\omega)$ produced by heterogeneous firms. ${ }^{2}$ For simplicity, we assume that the upper tier of utility determining consumption of the two industries' output is Cobb-Douglas and that the lower tier of utility determining consumption of varieties takes the CES form ${ }^{3}$,

$$
U=C_{1}^{\alpha_{1}} C_{2}^{\alpha_{2}}, \quad \alpha_{1}+\alpha_{2}=1, \alpha_{1}=\alpha
$$

where, to simplify notation, we omit the country superscript except where important.

$C_{i}$ is a consumption index defined over consumption of individual varieties, $q_{i}(\omega)$, with dual price index, $P_{i}$, defined over prices of varieties, $p_{i}(\omega)$,

$$
C_{i}=\left[\int_{\omega \in \Omega_{i}} q_{i}(\omega)^{\rho} d \omega\right]^{\frac{1}{\rho}}, \quad P_{i}=\left[\int_{\omega \in \Omega_{i}} p_{i}(\omega)^{1-\sigma} d \omega\right]^{\frac{1}{1-\sigma}},
$$

\footnotetext{
${ }^{2}$ Allowing one industry to produce a homogenous good under conditions of perfect competition and constant returns to scale (e.g. Agriculture) is a special case of this framework where, in one industry, the elasticity of substitution between varieties is infinite and the fixed production and sunk entry costs are zero.

${ }^{3}$ We use the terms "good", "sector", and "industry" synonymously while variety is reserved for a horizontally differentiated version within an industry. All we require is a utility function with an upper tier where industries' outputs are substitutes and a lower tier where consumer preferences exhibit a love of variety. See Melitz and Ottaviano (2003) for a single industry model where love of variety takes the quasi-linear form. We concentrate on the CES case to focus on the effects of relative factor abundance with homothetic preferences and to make our results comparable with the existing inter- and intra-industry trade literature (Helpman and Krugman 1985).
} 
where $\sigma=1 /(1-\rho)>1$ is the constant elasticity of substitution across varieties. For simplicity, we assume that the elasticity of substitution between varieties is the same in the two industries, but it is straightforward to allow this elasticity to vary.

\subsection{Production}

Production involves a fixed and variable cost each period. Both fixed and variable costs use multiple factors of production (skilled and unskilled labor) whose intensity of use varies across industries. All firms share the same fixed overhead cost but variable cost varies with firm productivity $\varphi \in(0, \infty)$. To avoid undue complexity, we assume that the cost function takes the Cobb-Douglas form, ${ }^{4}$

$$
\Gamma_{i}=\left[f_{i}+\frac{q_{i}}{\varphi}\right]\left(w_{S}\right)^{\beta_{i}}\left(w_{L}\right)^{1-\beta_{i}}, \quad 1>\beta_{1}>\beta_{2}>0
$$

where $w_{S}$ is the skilled wage and $w_{L}$ the unskilled wage, and industry 1 is assumed to be skill intensive relative to industry 2 . The presence of a fixed production cost implies that, in equilibrium, each firm will choose to produce a unique variety. The combination of monopolistic competition and variable costs that depend on firm productivity follows Melitz (2003). In contrast to that model, we incorporate factor intensity differences across sectors and factor abundance differences across countries. As a result, Heckscher-Ohlin comparative advantage now plays an important role in shaping heterogeneous firms' adjustment to international trade.

Consumer love of variety and costless trade implies that all producing firms also export. Since firms face the same elasticity of demand in both the domestic market, $d$, and the export market, $x$, and trade is costless, profit maximization implies the same equilibrium price in the two markets, equal to a constant mark-up over marginal cost:

$$
p_{i}(\varphi)=p_{i d}(\varphi)=p_{i x}(\varphi)=\frac{\left(w_{S}\right)^{\beta_{i}}\left(w_{L}\right)^{1-\beta_{i}}}{\rho \varphi} .
$$

With this pricing rule, firms' equilibrium domestic revenue, $r_{i d}(\varphi)$, will be proportional to productivity:

$$
r_{i d}(\varphi)=\alpha_{i} R\left(\frac{\rho P_{i} \varphi}{\left(w_{S}\right)^{\beta_{i}\left(w_{L}\right)^{1-\beta_{i}}}}\right)^{\sigma-1} .
$$

\footnotetext{
${ }^{4}$ The analysis generalizes in a relatively straightforward way to any homothetic cost function, for which the ratio of marginal cost to average cost will be a function of output alone. The assumption that fixed costs of production are independent of productivity captures the idea that many fixed costs, such as building and equipping a factory with machinery, are unlikely to vary substantially with firm productivity. All the analysis requires is that fixed costs are less sensitive to productivity than variable costs.
} 
For given firm productivity $\varphi$, domestic revenue is increasing in the share of expenditure allocated to an industry, $\alpha_{i}$, increasing in aggregate domestic expenditure (equals aggregate domestic revenue, $R$ ), increasing in the industry price index, $P_{i}$, which corresponds to an inverse measure of the degree of competition in a market, and increasing in $\rho$ which is an inverse measure of the size of the mark-up of price over marginal cost. Firm revenue is decreasing in own price and hence in own production costs.

The equilibrium pricing rule implies that the relative revenue of two firms with different productivity levels within the same industry and market depends solely on their relative productivity, as is clear from equation (5): $r_{i d}\left(\varphi^{\prime \prime}\right)=\left(\varphi^{\prime \prime} / \varphi^{\prime}\right)^{\sigma-1} r_{i d}\left(\varphi^{\prime}\right)$.

Revenue in the export market is determined analogously to the domestic market and, with firms charging the same equilibrium price, relative revenue in the two markets for a firm of given productivity, $\varphi$, will depend on relative country size, $R^{F} / R^{H}$, and the relative price index, $P_{i}^{F} / P_{i}^{H}$. With the prices of individual varieties equalized and all firms exporting under costless trade, the price indices will be the same in the two countries, $P_{i}^{F}=P_{i}^{H}$, and relative revenue will depend solely on relative country size. Total firm revenue is the sum of revenue in the domestic and export markets. Under the equilibrium pricing rule, firm profits will equal revenue from the two markets together scaled by the elasticity of substitution minus fixed costs of production:

$$
\begin{aligned}
& r_{i}(\varphi)=r_{i d}(\varphi)+r_{i x}(\varphi)=\left[1+\left(\frac{R^{F}}{R}\right)\right] r_{i d}(\varphi) \\
& \pi_{i}(\varphi)=\frac{r_{i}(\varphi)}{\sigma}-f_{i}\left(w_{S}\right)^{\beta_{i}}\left(w_{L}\right)^{1-\beta_{i}} .
\end{aligned}
$$

To produce in an industry, firms must pay a fixed entry cost, which is thereafter sunk. The entry cost also uses skilled and unskilled labor, and we begin by assuming that the factor intensity of entry and production are the same, so that the industry sunk entry cost takes the form:

$$
f_{e i}\left(w_{S}\right)^{\beta_{i}}\left(w_{L}\right)^{1-\beta_{i}}, \quad f_{e i}>0 .
$$

It is straightforward to relax the assumption of common factor intensities across the various stages of economic activity within industries. We discuss below how factor intensity differences between entry and production lead to additional interactions between country comparative advantage and the behavior of heterogeneous firms. 
After entry, firms draw their productivity, $\varphi$, from a distribution, $g(\varphi)$, which is assumed to be common across industries and countries. ${ }^{5}$ Firms then face an exogenous probability of death each period, $\delta$, which we interpret as due to force majeure events beyond managers' control. $^{6}$

A firm drawing productivity $\varphi$ will produce in an industry if its revenue, $r_{i}(\varphi)$, at least covers the fixed costs of production, i.e. $\pi_{i} \geq 0$. This defines a zero-profit productivity cutoff, $\varphi_{i}^{*}$, in each industry such that:

$$
r_{i}\left(\varphi_{i}^{*}\right)=\sigma f_{i}\left(w_{S}\right)^{\beta_{i}}\left(w_{L}\right)^{1-\beta_{i}} .
$$

Firms drawing productivity below $\varphi_{i}^{*}$ exit immediately, while those drawing productivity equal to or above $\varphi_{i}^{*}$ engage in profitable production. The value of a firm, therefore, is equal to zero if it draws a productivity below the zero-profit productivity cutoff and exits, or equal to the stream of future profits discounted by the probability of death if it draws a productivity above the cutoff value and produces:

$$
\begin{aligned}
v_{i}(\varphi) & =\max \left\{0, \sum_{t=0}^{\infty}(1-\delta)^{t} \pi_{i}(\varphi)\right\} \\
& =\max \left\{0, \frac{\pi_{i}(\varphi)}{\delta}\right\} .
\end{aligned}
$$

The ex post distribution of firm productivity, $\mu_{i}(\varphi)$, is conditional on successful entry and is truncated at the zero-profit productivity cutoff:

$$
\mu_{i}(\varphi)= \begin{cases}\frac{g(\varphi)}{1-G\left(\varphi_{i}^{*}\right)} & \text { if } \quad \varphi \geq \varphi_{i}^{*} \\ 0 & \text { otherwise }\end{cases}
$$

where $G(\varphi)$ is the cumulative distribution function for $g(\varphi)$, and $1-G\left(\varphi_{i}^{*}\right)$ is the ex ante probability of successful entry in an industry.

\footnotetext{
${ }^{5}$ Combining the assumptions of identical cost functions within an industry across countries and a common productivity distribution yields the standard Heckscher-Ohlin assumption of common technologies across countries. It is straightforward to allow for differences in productivity distributions across countries and industries. As in previous trade models with heterogeneous firms, e.g. Bernard et al. (2003) and Melitz (2003), we treat each firm's productivity level as fixed after entry. This assumption matches the empirical findings of Bernard and Jensen (1999), Clerides, Lach, and Tybout (1998) and others that there is no feedback from exporting to productivity at the firm level.

${ }^{6}$ The assumption that the probability of death is independent of firm characteristics is made for tractability to enable us to focus on the complex general equilibrium implications of international trade for firms, industries and countries. An existing literature examines industry dynamics in closed economies where productivity affects the probability of firm death (see, for example, Hopenhayn 1992 and Jovanovic 1982).
} 
There is an unbounded competitive fringe of potential entrants and, in an equilibrium with positive production of both goods, we require the expected value of entry, $V_{i}$, to equal the sunk entry cost in each industry. The expected value of entry is the ex ante probability of successful entry multiplied by the expected profitability of producing the good until death, and the free entry condition is thus:

$$
V_{i}=\frac{\left[1-G\left(\varphi_{i}^{*}\right)\right] \bar{\pi}_{i}}{\delta}=f_{e i}\left(w_{S}\right)^{\beta_{i}}\left(w_{L}\right)^{1-\beta_{i}}
$$

where $\bar{\pi}_{i}$ is expected or average firm profitability from successful entry. Equilibrium revenue and profit in each market are constant elasticity functions of firm productivity (equation (5)) and, therefore, average revenue and profit are equal respectively to the revenue and profit of a firm with weighted average productivity, $\bar{r}_{i}=r_{i}\left(\tilde{\varphi}_{i}\right)$ and $\bar{\pi}_{i}=\pi_{i}\left(\tilde{\varphi}_{i}\right)$, where weighted average productivity is determined by the ex post productivity distribution and hence the zero-profit productivity cutoff below which firms exit the industry:

$$
\widetilde{\varphi}_{i}\left(\varphi_{i}^{*}\right)=\left[\frac{1}{1-G\left(\varphi_{i}^{*}\right)} \int_{\varphi_{i}^{*}}^{\infty} \varphi^{\sigma-1} g(\varphi) d \varphi\right]^{\frac{1}{\sigma-1}}
$$

It proves useful for the ensuing analysis to re-write the free entry condition in a more convenient form. The equation for equilibrium profits above gives us an expression for the profits of a firm with weighted average productivity, $\bar{\pi}_{i}=\pi_{i}\left(\tilde{\varphi}_{i}\right)$. Given the equilibrium pricing rule, the revenue of a firm with weighted average productivity is proportional to the revenue of a firm with the zero-profit productivity, $r_{i}\left(\tilde{\varphi}_{i}\right)=\left(\tilde{\varphi}_{i} / \varphi_{i}^{*}\right)^{\sigma-1} r_{i}\left(\varphi_{i}^{*}\right)$, where the latter is proportional to the fixed cost of production in equilibrium, $r_{i}\left(\varphi_{i}^{*}\right)=\sigma f_{i}\left(w_{S}\right)^{\beta_{i}}\left(w_{L}\right)^{1-\beta_{i}}$. Combining these results with the definition of weighted average productivity above, the free entry condition can be written so that it is a function solely of the zero-profit productivity cutoff and parameters of the model:

$$
V_{i}=\frac{f_{i}}{\delta} \int_{\varphi_{i}^{*}}^{\infty}\left[\left(\frac{\varphi}{\varphi_{i}^{*}}\right)^{\sigma-1}-1\right] g(\varphi) d \varphi=f_{e i} .
$$

Terms in factor rewards have cancelled because average firm profitability and the sunk cost of entry are each proportional to factor costs, and entry and production have been assumed to have the same factor intensity. Since the middle term for the expected value of entry in equation (13) is monotonically decreasing in $\varphi_{i}^{*}$, this relationship alone uniquely pins down the zero-profit productivity cutoff independent of factor rewards and other endogenous variables of the model. If entry and production have different factor intensities, this will 
no longer be the case. The free entry condition will contain terms in factor rewards and, as discussed further below, movements in relative factor rewards have important implications for heterogeneous firms' decisions about whether or not to exit the industry based on their observed productivity.

This way of writing the free entry condition also makes clear how the zero-profit productivity cutoff is increasing in fixed production costs, $f_{i}$, and decreasing in the probability of firm death, $\delta$. Higher fixed production costs imply that firms must draw a higher productivity in order to earn sufficient revenue to cover the fixed costs of production. A higher probability of firm death reduces the mass of entrants into an industry, increasing ex post profitability, and therefore enabling firms of lower productivity to survive in the market.

\subsection{Goods Markets}

The steady-state equilibrium is characterized by a constant mass of firms entering an industry each period, $M_{e i}$, and a constant mass of firms producing within the industry, $M_{i}$. Thus, in steady-state equilibrium, the mass of firms who enter and draw a productivity sufficiently high to produce must equal the mass of firms who die:

$$
\left[1-G\left(\varphi_{i}^{*}\right)\right] M_{e i}=\delta M_{i}
$$

As noted above, under costless trade, firms charge the same price in the domestic and export markets and all firms export. Hence, the industry price indices are equalized across countries: $P_{i}^{F}=P_{i}^{H}$. A firm's equilibrium pricing rule implies that the price charged for an individual variety is inversely related to firm productivity, while the price indices are weighted averages of the prices charged by firms with different productivities, with the weights determined by the ex post productivity distribution. Exploiting this property of the price indices, we can write them as functions of the mass of firms producing in the home country multiplied by the price charged by a home firm with weighted average productivity, plus the mass of firms producing in the foreign country multiplied by the price charged by a foreign firm with weighted average productivity:

$$
P_{i}=P_{i}^{H}=P_{i}^{F}=\left[M_{i}^{H} p_{i}^{H}\left(\widetilde{\varphi}_{i}^{H}\right)^{1-\sigma}+M_{i}^{F} p_{i}^{F}\left(\widetilde{\varphi}_{i}^{F}\right)^{1-\sigma}\right]^{\frac{1}{1-\sigma}} .
$$

The larger the mass of firms producing in the two countries, and the lower the price charged by a firm with weighted average productivity in the two countries, the lower the value of the common industry price index. 
In equilibrium, we also require the goods market to clear at the world level, which requires the share of a good in the value of world production (in world revenue) to equal the share of a good in world expenditure:

$$
\frac{R_{1}+R_{1}^{F}}{R+R^{F}}=\alpha_{1}=\alpha .
$$

\subsection{Labor Markets}

Labor market clearing requires the demand for labor used in production and entry to equal labor supply as determined by countries' endowments:

$$
\begin{aligned}
S_{1}+S_{2} & =\bar{S}, & S_{i} & =S_{i}^{p}+S_{i}^{e} \\
L_{1}+L_{2} & =\bar{L}, & L_{i} & =L_{i}^{p}+L_{i}^{e}
\end{aligned}
$$

where $S$ denotes skilled labor, $L$ corresponds to unskilled labor, the superscript $p$ refers to a factor used in production, and the superscript $e$ refers to a factor used in entry.

\subsection{Integrated Equilibrium and Factor Price Equalization}

In this section, we describe the conditions for a free trade equilibrium characterized by factor price equalization (FPE). We begin by solving for the equilibrium of the integrated world economy, where both goods and factors are mobile, before showing that there exists a set of allocations of world factor endowments to the two countries individually such that the free trade equilibrium, with only goods mobile, replicates the resource allocation of the integrated world economy.

The integrated equilibrium is referenced by a vector of nine variables - the zero-profit cutoff productivities in each sector, the prices for individual varieties within each industry as a function of productivity, the industry price indices, aggregate revenue, and the two factor rewards: $\left\{\varphi_{1}^{*}, \varphi_{2}^{*}, P_{1}, P_{2}, R, p_{1}(\varphi), p_{2}(\varphi), w_{S}, w_{L}\right\}$. All other endogenous variables may be written as functions of these quantities. The equilibrium vector is determined by nine equilibrium conditions: firms' pricing rule (equation (4) for each sector), free entry (equation (13) for each sector), labor market clearing (equation (17) for the two factors), the values for the equilibrium price indices implied by consumer and producer optimization (equation (15) for each sector), and goods market clearing (equation (16)).

These conditions for integrated equilibrium are analogous to those in the standard framework of inter- and intra-industry trade with homogeneous firms (Helpman and Krugman 
1985). A key difference is that firm heterogeneity modifies the free entry condition which, instead of equating price and average cost, now equates the expected value and sunk costs of entry and defines the equilibrium zero-profit productivity cutoff, $\varphi_{i}^{*}$, below which firms exit the industry. Movements in this productivity cutoff involve resource reallocations within industries between firms and, in a way made precise below, may occur differentially across countries and industries in accordance with patterns of comparative advantage.

Proposition 1 There exists a unique integrated equilibrium, referenced by the vector $\left\{\hat{\varphi}_{1}^{*}\right.$, $\left.\hat{\varphi}_{2}^{*}, \hat{P}_{1}, \hat{P}_{2}, \hat{R}, \hat{p}_{1}(\varphi), \hat{p}_{2}(\varphi), \hat{w}_{S}, \hat{w}_{L}\right\}$. Under free trade, there exists a set of allocations of world factor endowments to the two countries individually such that the unique free trade equilibrium is characterized by factor price equalization (FPE) and replicates the resource allocation of the integrated world economy.

Proof. See Appendix

Factor price equalization requires that countries' endowments are sufficiently similar in the sense that their relative endowments of skilled and unskilled labor lie in between the integrated equilibrium factor intensities in the two sectors (Samuelson 1949; Dixit and Norman 1980). In the remainder of this section and in the next, we concentrate on equilibria characterized by FPE. In section 4 below, we analyze non-FPE equilibria associated with the existence of fixed and variable costs of trade. Throughout the following, we choose the skilled wage for the numeraire, and so $w_{S}=1$.

Our model allows us to keep track of a series of firm-level adjustment margins. One of these is the mass of firms across countries and industries, $M_{i}^{k}$ for $k \in\{H, F\}$, which depends upon total industry revenue, $R_{i}^{k}$, and average firm size, $\bar{r}_{i}^{k}$ :

$$
M_{i}^{k}=\frac{R_{i}^{k}}{\bar{r}_{i}^{k}} .
$$

Free entry into each sector implies that total payments to labor used in both entry and production equal total industry revenue, $R_{i}^{k}=w_{S}^{k} S_{i}^{k}+w_{L}^{k} L_{i}^{k} \cdot{ }^{7} \quad$ Therefore, industry revenue may be obtained from the common free trade equilibrium factor rewards $\left\{1, w_{L}\right\}$ and from the equilibrium allocation of labor to the two sectors $\left\{L_{i}^{k}, S_{i}^{k}\right\}$, which is uniquely pinned down by equilibrium factor rewards and countries' endowments. From the free trade equilibrium factor rewards and the zero-profit productivity cutoffs $\left\{\varphi_{i}^{* k}\right\}$, we can solve for

\footnotetext{
${ }^{7}$ See the proof of Proposition 1 for a formal derivation of this result.
} 
average firm size, $\bar{r}_{i}^{k}=r_{i}^{k}\left(\widetilde{\varphi}_{i}^{k}\right)=\left(\tilde{\varphi}_{i}^{k} / \varphi_{i}^{* k}\right)^{\sigma-1} \sigma f_{i}\left(w_{S}^{k}\right)^{\beta_{i}}\left(w_{L}^{k}\right)^{1-\beta_{i}}$. The existence of fixed production costs that use skilled and unskilled labor implies that equilibrium average firm size is proportional to factor rewards. Combining the expressions for industry revenue and average firm size yields the equilibrium mass of firms.

\section{Properties of the Free Trade Equilibrium}

We now examine the properties of the free trade equilibrium and the effects of moving from autarky to free trade. The analysis identifies a number of potential adjustment margins along which individual firms respond following the opening of trade - entry, exit and the overall mass of firms within an industry; average firm size; and the threshold productivity below which firms exit the industry. We begin by establishing that the relationship between production structure and factor abundance in the Heckscher-Ohlin model continues to hold in our heterogeneous-firm framework. We then show how firm-level margins of adjustment vary systematically across firms, industries and countries in accordance with comparative advantage.

\subsection{Endowments and Production Structure}

As in the Heckscher-Ohlin model, cross-country differences in factor abundance interact with cross-industry differences in factor intensity to determine production structure. Under autarky, home's relative skill abundance leads to a lower relative price of skilled labor and of the skill-intensive good. The opening of trade leads to a convergence in relative goods prices and relative factor rewards, so that the relative skilled wage rises in the skill-abundant home country and falls in the labor-abundant foreign country. The rise in the relative price of the skill-intensive good in the home country results in a reallocation of resources towards the skill-intensive sector, as each country specializes according to its pattern of comparative advantage.

Proposition 2 (a) Under free trade, countries devote a larger share of both types of labor to their comparative advantage industry; (b) The move from autarky to free trade increases the share of both types of labor allocated to the comparative advantage industry, (c) The move from autarky to free trade increases the relative reward of a country's abundant factor.

Proof. See Appendix 
Though in the interests of brevity we do not consider this in detail, all four theorems of the Heckscher-Ohlin model (Rybczynski, Heckscher-Ohlin, Stolper-Samuelson, and Factor Price Equalization) continue to hold, with only minor modifications to take into account monopolistic competition, firm heterogeneity and increasing returns to scale. Because there are multiple factors of production and trade changes relative factor rewards, the opening of trade has implications for the distribution of income within countries. We return to consider these implications in further detail below.

\subsection{Firm-level Responses}

Our heterogeneous-firm framework allows trade liberalization to have differential effects on firms within the same country and industry as well as on firms across countries and industries. We consider the distribution of productivity at producing firms, the number and average size of firms, as well as the amount of steady-state firm entry and exit. ${ }^{8}$

Proposition 3 In the free trade equilibrium: (a) the zero-profit productivity cutoff and average industry productivity are the same within industries across countries, $\left(\varphi_{i}^{* H}=\varphi_{i}^{* F}\right.$ and $\left.\widetilde{\varphi}_{i}^{H}=\widetilde{\varphi}_{i}^{F}\right)$, (b) average firm size is the same within industries across countries $\left(\bar{r}_{i}^{H}=\bar{r}_{i}^{F}\right)$, (c) countries have a larger relative mass of firms in their comparative advantage industry $\left(\frac{M_{1}^{H}}{M_{2}^{H}}>\frac{M_{1}^{F}}{M_{2}^{F}}\right)$, (d) countries experience relatively more entry and exit in their comparative advantage industry $\left(\frac{M_{e 1}^{H}}{M_{e 2}^{H}}>\frac{M_{e 1}^{F}}{M_{e 2}^{F}}\right)$.

Proof. See Appendix

Under free trade, all firms in each country have access to a single integrated market, and the zero-profit productivity cutoff is the same within industries across countries. This can be seen most clearly from the free entry condition (13), where $\varphi_{i}^{*}$ is pinned down by model parameters which, under the assumption of identical technologies, are the same across countries. Factor price equalization together with identical zero-profit productivity cutoffs means that average firm size is also the same across countries within industries.

In the free trade equilibrium, each country devotes a larger share of both types of labor to their comparative advantage industry. With average firm size the same across countries within industries, each country will have a larger relative mass of firms in its comparative advantage industry.

\footnotetext{
${ }^{8}$ Firm entry is associated with job creation and firm exit with job destruction so a corollary of increased entry and exit is a higher rate of job turnover within an industry.
} 
In steady-state equilibrium, the mass of entrants who draw a productivity above the zeroprofit threshold must equal the mass of firms who die. With the zero-profit productivity the same across countries, the mass of entrants varies proportionately with the mass of firms, and a larger relative mass of firms in a country's comparative advantage industry is reflected in a larger relative mass of entrants.

Proposition 4 With identical factor intensities in entry and production, a move from autarky to free trade (a) leaves the zero-profit productivity cutoff and average industry productivity unchanged $\left(\varphi_{i}^{*}\right.$ and $\left.\widetilde{\varphi}_{i}\right)$, (b) increases relative average firm size in a country's comparative advantage industry $\left(\frac{\bar{r}_{1}^{H}}{\bar{r}_{2}^{H}}\right.$ and $\left.\frac{\bar{r}_{2}^{F}}{\bar{r}_{1}^{F}}\right)$, (c) increases the relative mass of firms in a country's comparative advantage industry $\left(\frac{M_{1}^{H}}{M_{2}^{H}}\right.$ and $\left.\frac{M_{2}^{F}}{M_{1}^{F}}\right)$, and $(\boldsymbol{d})$ increases the relative amount of entry and exit in a country's comparative advantage industry $\left(\frac{M_{e 1}^{H}}{M_{e 2}^{H}}\right.$ and $\left.\frac{M_{e 2}^{F}}{M_{e 1}^{F}}\right)$.

Proof. See Appendix

With no trade costs, all firms export and are affected in the same way by the opening of trade. Firms of all productivities experience increased demand for their products in export markets and reduced demand in domestic markets as a result of entry by imported varieties. The mass of firms producing domestically in each industry, $M_{i}$, will change as countries specialize according to comparative advantage, and this will change the mass of firms producing at each level of productivity, $\mu_{i}\left(\varphi_{i}\right) M_{i}$, where $\mu_{i}\left(\varphi_{i}\right)$ is the ex post productivity distribution. Because firms of all productivities are affected symmetrically by the opening of trade, there is no change in the zero-profit productivity cutoff below which firms exit the industry and no change in average industry productivity.

This is again seen most clearly from the free entry condition (13). If the factor intensity of entry is the same as the factor intensity of production, $\varphi_{i}^{*}$ is pinned down by model parameters and is unchanged by the opening of trade. Although factor rewards do change following the opening of trade, the assumption that entry and production have the same factor intensity means that these changes in factor rewards affect both the value of entry (through firm profits) and entry costs in the same way. As a result, trade liberalization does not alter firms' entry decisions based on their observed productivity. ${ }^{9}$

\footnotetext{
${ }^{9}$ If we allow factor intensity to vary between entry and production, comparative advantage will influence the zero-profit productivity cutoff. For example, if entry is more skill-intensive than production, the fall in the relative skilled wage in the labor abundant country following the opening of trade will reduce the sunk costs of entry relative to the expected value of entry, inducing increased entry, an increase in the zero-
} 
In equilibrium, average firm size is proportional to the fixed costs of production, since these pin down the revenue of a firm with the lowest level of productivity in the market $\left(r\left(\varphi_{i}^{*}\right)=\sigma f_{i}\left(w_{S}\right)^{\beta_{i}}\left(w_{L}\right)^{1-\beta_{i}}\right)$, and the revenue of a firm with average productivity is proportional to the revenue of a firm with the zero-profit productivity $\left(r\left(\widetilde{\varphi}_{i}\right)=\left(\widetilde{\varphi}_{i} / \varphi_{i}^{*}\right)^{\sigma-1} r\left(\varphi_{i}^{*}\right)\right)$. In the move from autarky to free trade, the price of a country's abundant factor rises, which increases fixed costs of production in the industry using the abundant factor intensively relative to those in the other industry. The result is a rise in average firm size in a country's comparative advantage industry relative to the other industry.

Average firm size is one of the adjustment margins through which firms, industries and countries respond to trade. This novel feature of our framework contrasts with homogeneous-firm models of inter- and intra-industry trade, where the requirement that profits are equal to zero for all firms (rather than that the expected value of entry is equal to zero) means that average firm size is a constant determined by parameters of the model.

A second firm adjustment margin is the mass of firms. In the move from autarky to free trade, each country allocates a greater share of both factors of production to the comparative advantage industry, increasing the mass of firms in that industry relative to the comparative disadvantage industry.

This change in the mass of firms has implications for entry and exit as a margin of adjustment. If the factor intensity of entry is the same as the factor intensity of production, the zero-profit productivity cutoff in each industry is unchanged by the opening of trade, and the mass of entrants moves proportionately with the mass of firms. The rise in the relative mass of firms in the comparative advantage industry is reflected in a rise in the relative amount of entry and exit.

The opening of free trade is thus associated with changes in average firm size, changes in the mass of firms, and changes in the extent of entry and exit. These changes occur differentially across countries and industries in accordance with comparative advantage, with average firm size, the mass of firms, and the extent of entry and exit rising in comparative advantage industries relative to comparative disadvantage industries.

With differences in factor intensity between entry and production, the movements in relative factor rewards due to the opening of trade would lead to changes in the zero profit productivity cutoff and within-industry reallocations of resources. In the next section, we

profit productivity cutoff, and an improvement in aggregate industry productivity. See Flam and Helpman (1987) for an exploration of factor intensity differences between fixed and variable production costs in a homogeneous firm model of trade. 
show how relaxing the assumption of costless trade also leads to changes in the productivity range of producing firms in ways that are shaped by the interaction of factor intensity and factor abundance.

\section{Costly Trade}

The assumption that trade is perfectly costless is at odds with recent empirical evidence of sizeable trade costs. ${ }^{10}$ This empirical literature suggests that there are important fixed costs of entering foreign markets, such as the costs of acquiring information about foreign markets, developing appropriate marketing strategies and building distribution networks. ${ }^{11}$

In this section, we introduce fixed and variable costs of trade as in the single-industry model of Melitz (2003). We show how trade costs interact with comparative advantage to determine responses to trade liberalization that vary across firms, industries and countries. Factor intensity and factor abundance, which have traditionally been viewed as determining reallocations of resources between industries, also play an important role in shaping withinindustry reallocations of resources from less to more productive firms.

The basic setup remains the same as under free trade. However, in order to export a manufacturing variety to a particular market, a firm must incur a fixed export cost, which uses both skilled and unskilled labor with the same factor intensities as production. In addition, the firm may also face variable trade costs, which take the standard iceberg form whereby a fraction $\tau_{i}>1$ units of a good must be shipped in industry $i$ in order for one unit to arrive. ${ }^{12}$ These fixed and variable trade costs mean that, depending on their productivity, some firms may choose not to export in equilibrium.

\subsection{Consumption and Production}

Profit maximization implies that equilibrium prices are again a constant mark-up over marginal cost, with export prices a constant multiple of domestic prices due to the variable costs of trade:

$$
p_{i x}^{H}(\varphi)=\tau_{i} p_{i d}^{H}(\varphi)=\frac{\tau_{i}\left(w_{S}^{H}\right)^{\beta_{i}}\left(w_{L}^{H}\right)^{1-\beta_{i}}}{\rho \varphi} .
$$

Given firms' pricing rules, equilibrium revenue in the export market is proportional to that in the domestic market. However, the price differences between the two markets mean

\footnotetext{
${ }^{10}$ See, in particular, Anderson and van Wincoop (2004) and Hummels (2001).

${ }^{11}$ See, for example, Roberts and Tybout (1997a), (1997b) and Bernard and Jensen (2004).

${ }^{12}$ In the analysis below, we write out expressions for home explicitly; those for foreign are analogous.
} 
that relative revenue in the export market depends now directly on variable trade costs. Furthermore, price indices now vary across the two countries due to variation in the mass of firms producing in an industry, different prices charged by firms in domestic and export markets (variable trade costs), and the existence of both exporters and non-exporters (fixed and variable trade costs). As a result, relative price indices enter as a determinant of relative revenue in the export market:

$$
r_{i x}^{H}(\varphi)=\tau_{i}^{1-\sigma}\left(\frac{P_{i}^{F}}{P_{i}^{H}}\right)^{\sigma-1}\left(\frac{R^{F}}{R^{H}}\right) r_{i d}^{H}(\varphi) .
$$

The wedge between revenue in the export and domestic markets in equation (20) will typically vary across countries and industries, and will prove important in determining how trade liberalization increases the expected value of entry into an industry. Total revenue received by home firms is:

$$
r_{i}^{H}(\varphi)= \begin{cases}r_{i d}^{H}(\varphi) & \text { if does not export } \\ r_{i d}^{H}(\varphi)\left[1+\tau_{i}^{1-\sigma}\left(\frac{P_{i}^{F}}{P_{i}^{H}}\right)^{\sigma-1}\left(\frac{R^{F}}{R^{H}}\right)\right] & \text { if exports. }\end{cases}
$$

Consumer love of variety and fixed production costs imply that no firm will ever export without also producing for the domestic market. Therefore, we may separate each firm's profit into components earned from domestic sales, $\pi_{i d}^{H}(\varphi)$, and foreign sales, $\pi_{i x}^{H}(\varphi)$, where we apportion the entire fixed production cost to domestic profit and the fixed exporting cost to foreign profit: ${ }^{13}$

$$
\begin{aligned}
& \pi_{i d}^{H}(\varphi)=\frac{r_{i d}^{H}(\varphi)}{\sigma}-f_{i}\left(w_{S}^{H}\right)^{\beta_{i}}\left(w_{L}^{H}\right)^{1-\beta_{i}} \\
& \pi_{i x}^{H}(\varphi)=\frac{r_{i x}^{H}(\varphi)}{\sigma}-f_{i x}\left(w_{S}^{H}\right)^{\beta_{i}}\left(w_{L}^{H}\right)^{1-\beta_{i}}
\end{aligned}
$$

where the fixed cost of exporting requires both skilled and unskilled labor, $f_{i x}\left(w_{S}^{H}\right)^{\beta_{i}}\left(w_{L}^{H}\right)^{1-\beta_{i}} .^{14}$ A firm which produces for its domestic market also exports if $\pi_{i x}^{H}(\varphi)>0$, and total firm profit is given by:

$$
\pi_{i}^{H}(\varphi)=\pi_{i d}^{H}(\varphi)+\max \left\{0, \pi_{i x}^{H}(\varphi)\right\} .
$$

\footnotetext{
${ }^{13}$ This is a convenient accounting device which simplifies the exposition. Rather than comparing revenue from exporting to the fixed cost of exporting, we could equivalently compare the sum of domestic and export revenue to the sum of fixed production and exporting costs.

${ }^{14}$ We assume that fixed export costs use domestic factors of production, consistent with the idea that resources must be set aside to acquire information about and to enter foreign markets. One could also introduce a component of fixed export costs that employed factors of production in the foreign market. However, this would introduce Foreign Direct Investment (FDI) into the model, while our focus is on the relationship between international trade, heterogeneous firms and comparative advantage. See Helpman, Melitz and Yeaple (2004) for an analysis of FDI in a single-factor model of heterogeneous firms.
} 


\subsection{Decision to Produce and Export}

After firms have paid the sunk cost of entering an industry, they draw their productivity, $\varphi$, from the distribution $g(\varphi)$. There are now two cutoff productivities, the costly-trade zero-profit productivity cutoff, $\varphi_{i}^{* H}$, above which firms produce for the domestic market and the costly-trade exporting productivity cutoff, $\varphi_{i x}^{* H}$, above which firms produce for both the domestic and export markets:

$$
\begin{aligned}
r_{i d}^{H}\left(\varphi_{i}^{* H}\right) & =\sigma f_{i}\left(w_{S}^{H}\right)^{\beta_{i}}\left(w_{L}^{H}\right)^{1-\beta_{i}} \\
r_{i x}^{H}\left(\varphi_{i x}^{* H}\right) & =\sigma f_{i x}\left(w_{S}^{H}\right)^{\beta_{i}}\left(w_{L}^{H}\right)^{1-\beta_{i}} .
\end{aligned}
$$

Combining these two expressions, we obtain one equation linking the revenues of a firm at the zero-profit productivity cutoff to those of a firm at the exporting productivity cutoff. A second equation is obtained from the relationship between the revenues of two firms with different productivities within the same market, $r_{i d}\left(\varphi^{\prime \prime}\right)=\left(\varphi^{\prime \prime} / \varphi^{\prime}\right)^{\sigma-1} r_{i d}\left(\varphi^{\prime}\right)$, and from the relationship between revenues in the export and domestic markets, equation (20). The two equations together yield an equilibrium relationship between the two productivity cutoffs:

$$
\varphi_{i x}^{* H}=\Lambda_{i}^{H} \varphi_{i}^{* H} \quad \text { where } \quad \Lambda_{i}^{H} \equiv \tau_{i}\left(\frac{P_{i}^{H}}{P_{i}^{F}}\right)\left(\frac{R^{H}}{R^{F}} \frac{f_{i x}}{f_{i}}\right)^{\frac{1}{\sigma-1}} .
$$

The exporting productivity cutoff will be high relative to the zero-profit productivity cutoff, i.e. only a small fraction of firms will export, when the fixed cost of exporting, $f_{i x}$, is large relative to the fixed cost of production, $f_{i}$. In this case, the revenue required to cover the fixed export cost is large relative to the revenue required to cover fixed production costs, implying that only firms of high productivity will find it profitable to serve both markets. The exporting productivity cutoff will also be high relative to the zero-profit productivity cutoff when the home price index, $P_{i}^{H}$, is high relative to the foreign price index, $P_{i}^{F}$, and the home market, $R^{H}$, is large relative to the foreign market, $R^{F}$. Again, only high-productivity firms receive enough revenue in the relatively small and competitive foreign market to cover the fixed cost of exporting. Finally, higher variable trade costs increase the exporting productivity cutoff relative to the zero-profit productivity cutoff by increasing prices and reducing revenue in the export market.

For values of $\Lambda_{i}^{k}>1$, there is selection into markets, i.e. only the most productive firms export. Since empirical evidence strongly supports selection into export markets and the interior equilibrium is the most interesting one, we focus throughout the following on 
parameter values where $\Lambda_{i}^{k}>1$ across countries $k$ and industries $i{ }^{15}$

Firms' decisions concerning production for the domestic and foreign markets are summarized graphically in Figure 1. Of the mass of firms $M_{e i}^{H}$ who enter the industry each period, a fraction, $G\left(\varphi_{i}^{* H}\right)$, draw a productivity level sufficiently low that they are unable to cover fixed production costs and exit the industry immediately; a fraction, $G\left(\varphi_{i x}^{* H}\right)-G\left(\varphi_{i}^{* H}\right)$, draw an intermediate productivity level such that they are able to cover fixed production costs and serve the domestic market, but are not profitable enough to export; and a fraction, $G\left(\varphi_{i x}^{* H}\right)$, draw a productivity level sufficiently high that it is profitable to serve both the home and foreign markets in equilibrium.

The ex ante probability of successful entry is $\left[1-G\left(\varphi_{i}^{* H}\right)\right]$ and the ex ante probability of exporting conditional on successful entry is:

$$
\chi_{i}^{H}=\frac{\left[1-G\left(\varphi_{i x}^{* H}\right)\right]}{\left[1-G\left(\varphi_{i}^{* H}\right)\right]} .
$$

\subsection{Free Entry}

In an equilibrium with positive production of both goods, we again require the expected value of entry, $V_{i}^{H}$, to equal the sunk entry cost in each industry. The expected value of entry is now the sum of two terms: the ex ante probability of successful entry times the expected profitability of producing the good for the domestic market until death and the $e x$ ante probability of successful entry times the probability of exporting times the expected profitability of producing the good for the export market until death:

$$
V_{i}=\frac{\left[1-G\left(\varphi_{i}^{*}\right)\right]}{\delta}\left[\bar{\pi}_{i d}^{H}+\chi_{i}^{H} \bar{\pi}_{i x}^{H}\right]=f_{e i}\left(w_{S}\right)^{\beta_{i}}\left(w_{L}\right)^{1-\beta_{i}}
$$

where average profitability in each market is equal to the profit of a firm with weighted average productivity, $\bar{\pi}_{i d}^{H}=\pi_{i d}^{H}\left(\widetilde{\varphi}_{i}^{H}\right)$ and $\bar{\pi}_{i x}^{H}=\pi_{i x}^{H}\left(\widetilde{\varphi}_{i x}^{H}\right)$. Some lower-productivity firms do not export which leads to higher weighted average productivity in the export market than in the domestic market. Weighted average productivity is defined as in equation (12), where the relevant cutoff for the domestic market is the zero-profit productivity, $\varphi_{i}^{*}$, and the relevant cutoff for the export market is the exporting productivity, $\varphi_{i x}^{*}$.

\footnotetext{
${ }^{15}$ For empirical evidence on selection into export markets, see Bernard and Jensen (1995, 1999, 2004), Clerides, Lach and Tybout (1998), and Roberts and Tybout (1997a).
} 
Following the same line of reasoning as under free trade, we can write the free entry condition as a function of the two productivity cutoffs and model parameters:

$$
V_{i}^{H}=\frac{f_{i}}{\delta} \int_{\varphi_{i}^{* H}}^{\infty}\left[\left(\frac{\varphi}{\varphi_{i}^{* H}}\right)^{\sigma-1}-1\right] g(\varphi) d \varphi+\frac{f_{i x}}{\delta} \int_{\varphi_{i x}^{* H}}^{\infty}\left[\left(\frac{\varphi}{\varphi_{i x}^{* H}}\right)^{\sigma-1}-1\right] g(\varphi) d \varphi=f_{e i} \text {. }
$$

The expression for the expected value of entry now consists of two separate terms that take into account the difference in profitability between firms who only serve the domestic market and those who serve both domestic and export markets (previously, under free trade, all firms exported). In equilibrium, $\varphi_{i x}^{*}$ and $\varphi_{i}^{*}$ are related according to equation (25). The distance in productivity between the least productive firm able to survive in the domestic market and the least productive firm able to survive in the export market depends on industry price indices and country size, and will hence vary systematically across countries and industries.

\subsection{Goods and Labor Markets}

Again, in steady-state, the mass of firms who enter an industry and draw a productivity high enough to produce equals the mass of firms who die.

Using the equilibrium pricing rule, the industry price indices may be written as:

$$
P_{i}^{H}=\left[M_{i}^{H}\left(p_{i d}^{H}\left(\widetilde{\varphi}_{i}^{H}\right)\right)^{1-\sigma}+\chi_{i}^{F} M_{i}^{F}\left(\tau_{i} p_{i d}^{F}\left(\widetilde{\varphi}_{i x}^{F}\right)\right)^{1-\sigma}\right]^{\frac{1}{1-\sigma}} .
$$

In general, the price indices for an industry will now vary across countries because of differences in the number of domestic and foreign firms, differences in domestic and export prices (variable trade costs captured by $\tau_{i}$ ), and differences in the proportion of exporting firms (fixed and variable trade costs reflected in $\chi_{i}^{F}$ and $\widetilde{\varphi}_{i x}^{F}$ ).

In equilibrium, we also require that the sum of domestic and foreign expenditure on domestic varieties equals the value of domestic production (total industry revenue, $R_{i}$ ) for each industry and country:

$$
R_{i}^{H}=\alpha_{i} R^{H} M_{i}^{H}\left(\frac{p_{i d}^{H}\left(\tilde{\varphi}_{i}^{H}\right)}{P_{i}^{H}}\right)^{1-\sigma}+\alpha_{i} R^{F} \chi_{i}^{H} M_{i}^{H}\left(\frac{\tau_{i} p_{i d}^{H}\left(\tilde{\varphi}_{i x}^{H}\right)}{P_{i}^{F}}\right)^{1-\sigma}
$$

where, with free entry into each industry, total industry revenue equals total labor payments, $R_{i}^{H}=w_{S}^{H} S_{i}^{H}+w_{L}^{H} L_{i}^{H}$. Requiring that equation (30) holds for all countries and industries implies that the goods markets clear at the world level. 
The first term on the right-hand side of equation (30) captures home expenditure on home varieties, which equals the mass of varieties sold domestically, $M_{i}^{H}$, times expenditure on a variety with weighted average productivity. ${ }^{16}$ The second term on the right-hand side of equation (30) captures foreign expenditure on home varieties. The key differences between the two terms are that only some of the varieties produced in home are exported to foreign (captured by the probability of exporting $\chi_{i}^{H}$ ), the price charged by home producers in the export market is higher than in the domestic market (variable trade $\operatorname{costs} \tau_{i}$ ), and the weighted average productivity in the export market is greater than in the domestic market because of entry into export markets only by higher productivity firms.

\subsection{Costly Trade Equilibrium}

The costly trade equilibrium is referenced by a vector of thirteen variables in home and foreign: $\left\{\varphi_{1}^{* k}, \varphi_{2}^{* k}, \varphi_{1 x}^{* k}, \varphi_{2 x}^{* k}, P_{1}^{k}, P_{2}^{k}, p_{1}^{k}(\varphi), p_{2}^{k}(\varphi), p_{1 x}^{k}(\varphi), p_{2 x}^{k}(\varphi), w_{S}^{k}, w_{L}^{k}, R^{k}\right\}$ for $k \in\{H, F\}$. All other endogenous variables may be written as functions of these quantities. The equilibrium vector is determined by the following equilibrium conditions for each country: firms' pricing rule (equation (19) for each industry and for the domestic and export market separately), free entry (equation (28) for each sector), the relationship between the two productivity cutoffs (equation (25) for each sector), labor market clearing (equation (17) for the two factors), the values for the equilibrium price indices implied by consumer and producer optimization (equation (29) for each sector), and world expenditure on a country's output of a good equals the value of the country's production (equation (30) for each sector).

Proposition 5 There exists a unique costly trade equilibrium referenced by the pair of equilibrium vectors, $\left\{\hat{\varphi}_{1}^{* k}, \hat{\varphi}_{2}^{* k}, \hat{\varphi}_{1 x}^{* k}, \hat{\varphi}_{2 x}^{* k}, \hat{P}_{1}^{k}, \hat{P}_{2}^{k}, \hat{p}_{1}^{k}(\varphi), \hat{p}_{2}^{k}(\varphi), \hat{p}_{1 x}^{k}(\varphi), \hat{p}_{2 x}^{k}(\varphi), \hat{w}_{S}^{k}, \hat{w}_{L}^{k}\right.$, $\left.\hat{R}^{k}\right\}$ for $k \in\{H, F\}$.

Proof. See Appendix.

Following the opening of costly trade, the relative price indices for the two goods will lie in between their autarky and free trade values, and will differ across the two countries, with

\footnotetext{
${ }^{16}$ Expenditure on a variety with weighted average productivity depends negatively on the domestic price of such a variety, $p_{i d}^{H}\left(\tilde{\varphi}_{i}^{H}\right)$, positively on the price of competing varieties (including those produced in foreign and exported to home) as summarized in the domestic price index, $P_{i}^{H}$, positively on the share of consumer expenditure devoted to a good in equilibrium, $\alpha_{i}$, and positively on aggregate home expenditure (equals aggregate home revenue, $R^{H}$ ).
} 
the skill-abundant country characterized by a lower relative price index for the skill-intensive good. These cross-country differences in relative price indices will be reflected in general equilibrium in cross-country differences in relative factor rewards, with the skill-abundant country having a lower relative skilled wage. ${ }^{17}$ Cross-country differences in both relative price indices and relative factor rewards have important implications for how heterogeneous firms adjust to trade, as examined in the next section.

\section{Properties of the Costly Trade Equilibrium}

As in single-industry models of heterogeneous firms, the opening to costly trade is followed by compositional changes within industries, which increase aggregate industry productivity. Unlike those single-industry models, the degree of within-industry reallocation varies systematically with comparative advantage, as driven by Heckscher-Ohlin considerations of relative factor abundance and factor intensity.

The combination of multiple factors, multiple countries, asymmetric countries, heterogeneous firms, and trade costs means that there are no longer closed form solutions for several key endogenous variables of the model. Nonetheless, we are able to derive a number of analytical results concerning the effects of opening a closed economy to costly trade. We begin by developing these analytical results. In section 6 , we numerically solve the model, illustrate the analytical results for a particular parameterization of the model, and trace the evolution of the endogenous variables for which no closed form solution exists.

\subsection{Productivity and the Probability of Exporting}

With trade costs, not all firms find it profitable to export. As a result, trade has a differential effect on the profits of exporting and non-exporting firms. This contrasts with free trade, where all firms exported and were affected by trade in the same way. With comparative advantage, the profits derived from exporting vary systematically across countries and industries. Thus with costly trade, the extent to which the profits of exporters change relative to the profits of non-exporters depends on comparative advantage. The combination of these two forces (selection into export markets and the profitability of exporting varying with comparative advantage) lie at the heart of the uneven within-industry reallocations of resources in the model.

\footnotetext{
${ }^{17}$ See Markusen and Venables (2000) for an analysis of trade costs and non-factor price equalization in homogeneous-firm models of inter- and intra-industry trade.
} 
From equation (21), the magnitude of the profits to be derived from the export market relative to the domestic market depends on market size (as captured by aggregate revenue, $R$ ), the degree of competition in the two markets (as captured by the price indices $P_{i}$ ), and trade costs $\left(f_{i x}\right.$ and $\left.\tau_{i}\right)$.

We begin by showing how these characteristics of countries and industries matter by comparing costly trade equilibria with different values for countries' aggregate revenue, price indices and trade costs. Of course, aggregate revenue and price indices are endogenously determined and, in the next stage of the analysis, we link these endogenous variables to exogenous characteristics of countries and industries in the form of relative factor abundance and relative factor intensity.

Proposition 6 (a) The opening of a closed economy to international trade with positive fixed and variable trade costs will increase the zero-profit productivity cutoff, $\varphi_{i}^{*}$, below which firms exit, and will increase average productivity, $\widetilde{\varphi}_{i}$, in both industries,

(b) other things equal, the zero-profit productivity cutoff, $\varphi_{i}^{*}$, and average industry productivity, $\widetilde{\varphi}_{i}$, will rise by more if a country is small relative to its trade partner $\left(R^{H}\right.$ small relative to $R^{F}$ ), if domestic competition is high relative to foreign competition within the industry $\left(P_{i}^{H}\right.$ low relative to $\left.P_{i}^{F}\right)$, or if fixed and variable trade costs are low $\left(f_{i x}\right.$ and $\tau_{i}$ small),

(c) the probability of exporting $\left(\chi_{i}=\left[1-G\left(\varphi_{i x}^{*}\right)\right] /\left[1-G\left(\varphi_{i}^{*}\right)\right]\right)$ will be greater when home is small relative to foreign ( $R^{H}$ small relative to $R^{F}$ ), when domestic competition is high relative to foreign competition within the industry $\left(P_{i}^{H}\right.$ low relative to $\left.P_{i}^{F}\right)$, or when fixed and variable trade costs are low ( $f_{i x}$ and $\tau_{i}$ small).

Proof. See Appendix

The rise in the zero-profit productivity cutoff in both industries can be understood as follows. Moving from autarky to costly trade, the ex post profits of more productive exporting firms rise. This increases the expected value of entry in each industry because there is a positive ex ante probability of drawing a productivity sufficiently high to export. Other things equal, this increases the mass of entrants in the industry, which reduces the $e x$ post profits of low-productivity firms who only serve the domestic market. As a result, some low-productivity domestic firms no longer receive enough revenue to cover fixed production costs and exit the industry, so that the zero-profit productivity cutoff, $\varphi_{i}^{*}$, and average industry productivity, $\widetilde{\varphi}_{i}$, rise. $^{18}$

\footnotetext{
${ }^{18}$ Starting from autarky and reducing trade costs, the zero profit productivity cutoff will rise as long as
} 
The rise in the ex post profits of more productive exporting firms will be greater when the home market is small relative to the foreign market, when the degree of competition in the domestic market is high relative to the foreign market, and when trade costs are low. Therefore, the increase in entry, the reduction in profits of firms only serving the domestic market, the increase in the zero-profit cutoff productivity, and the increase in average industry productivity will be larger in countries and industries with these characteristics.

An increase in profits in the export market relative to those in the domestic market also raises the probability that a firm will export. Therefore, the probability of exporting will be greater when home is small relative to foreign, when the degree of competition in the domestic market is high relative to the foreign market and when trade costs are low.

These results imply that, other things equal, average productivity and the probability of exporting will be higher in small countries. The other key characteristic of countries and industries that matters for average productivity and the probability of exporting is the degree of competition as captured by the price indices, $P_{i}^{k}$. Trade costs mean that the price indices vary across countries and industries with the mass of firms producing in home and foreign, and therefore depend on comparative advantage.

Proposition 7 Other things equal, the opening of a closed economy to costly international trade will:

(a) raise the zero-profit productivity cutoff in a country's comparative advantage industry $\left(\varphi_{1}^{* H}\right.$ and $\left.\varphi_{2}^{* F}\right)$ by more than in the comparative disadvantage industry $\left(\varphi_{2}^{* H}\right.$ and $\left.\varphi_{1}^{* F}\right)$;

(b) magnify comparative advantage by inducing endogenous Ricardian productivity differences at the industry level, which are positively correlated with Heckscher-Ohlin-based comparative advantage $\left(\widetilde{\varphi}_{1}^{H} / \widetilde{\varphi}_{2}^{H}>\widetilde{\varphi}_{1}^{F} / \widetilde{\varphi}_{2}^{F}\right)$

(c) result in a higher probability of exporting in a country's comparative advantage industry $\left(\chi_{1}^{H}\right.$ and $\left.\chi_{2}^{F}\right)$ than in the comparative disadvantage industry $\left(\chi_{2}^{H}\right.$ and $\left.\chi_{1}^{F}\right)$.

\section{Proof. See Appendix}

Under costly trade, the skill-abundant home country will devote a greater share of its

there is selection into export markets. As trade costs continue to fall, there will eventually come a point where all firms export. From this point onwards, further reductions in trade costs increase ex post profitability for all firms, reducing the value of the zero profit productivity above which firms can profitably produce, until free trade is attained at which point the cutoff takes the same value as under autarky. The same values for the zero profit productivity cutoff under autarky and free trade follow from the cutoff being independent of market size and relative factor prices (under free trade, the world is a single integrated market). We focus on parameter values where there is selection into export markets since this is the empirically relevant case. 
skilled and unskilled labor to the skill-intensive industry, generating a larger relative mass of firms in the skill-intensive industry. With variable trade costs introducing a wedge between domestic and export prices, and fixed and variable trade costs separating firms into exporters and non-exporters, these cross-country differences in the relative mass of firms translate into a lower relative price of the skill-intensive good in the skill-abundant home country.

The lower relative price of the skill-intensive good in the home country means that producers of the skill-intensive good face relatively more intense competition in the home market. Similarly, the lower relative price of the labor-intensive good in the foreign country means that producers of the labor-intensive good face relatively more intense competition in the foreign market. In each case, there is lower competition in the export market in the comparative advantage industry, which means a larger increase in profits for exporters and a greater increase in the expected value of entering the industry. This, in turn, induces a larger increase in the mass of entrants and a greater reduction in the profits of firms only serving the domestic market. The resulting shift in activity across firms leads to a larger increase in the zero-profit productivity cutoff, below which firms exit the industry, a larger increase in average industry productivity, and a higher probability of exporting in the comparative advantage industry.

Another way to gain intuition for the greater exit of low productivity firms, the stronger within-industry reallocation, and the greater increase in average productivity in comparative advantage industries comes from thinking about the general equilibrium implications for the labor market. Opening to costly trade leads to an increase in labor demand at exporters. This increase in labor demand bids up factor prices, reducing the ex post profits of nonexporters, and increasing the zero-profit productivity below which firms exit the industry.

The increase in labor demand at exporters is larger in the comparative advantage industry than in the comparative disadvantage industry, resulting in a rise in the relative price of the abundant factor. This rise in the relative price of the abundant factor leads to a greater reduction in the ex post profits of firms only serving the domestic market in the comparative advantage industry which uses the abundant factor intensively. As a result, the zero-profit productivity cutoff and average industry productivity rise by more in the comparative advantage industry. This does not occur under free trade because firms of all productivities benefit from the increase in demand generated by access to export markets.

The links between comparative advantage, the zero-profit productivity cutoff, and the probability of exporting are given formally in the equilibrium relationship between the two 
productivity cutoffs (equation (25)). Dividing this relationship in one industry by the same relationship in the other industry, we obtain:

$$
\frac{\Lambda_{1}^{H}}{\Lambda_{2}^{H}} \equiv \frac{\varphi_{1 x}^{* H} / \varphi_{1}^{* H}}{\varphi_{2 x}^{* H} / \varphi_{2}^{* H}}=\frac{\tau_{1}}{\tau_{2}}\left(\frac{f_{1 x} / f_{1}}{f_{2 x} / f_{2}}\right)^{\frac{1}{\sigma-1}} \frac{P_{1}^{H} / P_{2}^{H}}{P_{1}^{F} / P_{2}^{F}} .
$$

where the effect of aggregate country revenue on the relative value of the two cutoffs has cancelled because it has the same effect in both industries.

Fixed and variable trade costs are one determinant of the relative value of the exporting and zero-profit cutoff productivities across industries. However, other things equal (i.e. abstracting from cross-industry differences in trade costs), the relative value of the two cutoffs depends solely on relative price indices.

Under both autarky and costly trade, the relative price index for the skill-intensive good will be lower in the skill-abundant country. Therefore, in the skill-abundant country, the exporting productivity cutoff will be closer to the zero-profit productivity cutoff in the skill-intensive industry than in the labor-intensive industry $\left(\Lambda_{1}^{H}<\Lambda_{2}^{H}\right)$. This implies a greater increase in the expected value of entering the industry following the opening of costly trade (equation (28)), and so a larger increase in the zero-profit productivity cutoff and average industry productivity in the comparative advantage industry. It also implies a higher probability of exporting in the comparative advantage industry (equation (26)). These implications of comparative advantage for the zero-profit and exporting productivity cutoffs are summarized graphically in Figure 2.

\subsection{Endogenous Ricardian Comparative Advantage}

The larger rise in average industry productivity in a country's comparative advantage industry leads to the emergence of endogenous Ricardian productivity differences at the industry level, which amplify Heckscher-Ohlin comparative advantage:

$$
\frac{\widetilde{\varphi}_{1}^{H}}{\widetilde{\varphi}_{2}^{H}}>\frac{\widetilde{\varphi}_{1}^{F}}{\widetilde{\varphi}_{2}^{F}} .
$$

We refer to the ratio of these quantities as the magnification of comparative advantage. These endogenous industry-level productivity differences are driven solely by the greater selection of high-productivity firms in comparative advantage industries. Their emergence has general equilibrium implications for the size of the reallocation of resources between industries, equilibrium relative factor rewards, equilibrium real factor rewards (and hence 
welfare) and patterns of international trade. Consider, for example, real consumption wages which depend on nominal wages and the consumer price indices:

$$
W_{S}^{H}=\frac{w_{S}^{H}}{\left(P_{1}^{H}\right)^{\alpha}\left(P_{2}^{H}\right)^{1-\alpha}}, \quad W_{L}^{H}=\frac{w_{L}^{H}}{\left(P_{1}^{H}\right)^{\alpha}\left(P_{2}^{H}\right)^{1-\alpha}} .
$$

In the standard Heckscher-Ohlin model, the rise in the relative price of a country's comparative advantage good following the opening of trade leads to a rise in the real reward of the abundant factor and a decline in the real reward of the scarce factor. In our heterogeneous-firm framework, this Stolper-Samuelson effect continues to operate but it is augmented with an additional effect.

Since the opening of trade will raise average industry productivity in both sectors, this will lead to a decrease in the average price of individual varieties which will reduce the consumer price index for both goods, and so increase the real reward of both factors. In addition, as in Helpman-Krugman (1985), the opening of trade may expand the number of varieties available for domestic consumption, which would decrease the consumer price index for both goods, and so increase the real reward of both factors. ${ }^{19}$

If the productivity and variety effects are sufficiently large, it becomes possible for both factors of production to gain from international trade, and we present an example of this in the numerical solutions section below. More generally, the existence of these productivity and variety effects means that the real reward of the abundant factor will rise by more than in the standard Heckscher-Ohlin framework and the real reward of the scarce factor will fall by less than in the standard framework.

Combining heterogeneous firms with Heckscher-Ohlin based comparative advantage modifies the model's general equilibrium predictions for the effects of opening to trade on income distribution and welfare. The uneven selection of high-productivity firms across industries also has general equilibrium effects on resource reallocation and patterns of international trade, to which we return below.

\subsection{Firm Size, Mass of Firms, Entry and Exit}

The opening of costly trade will lead to changes in relative firm size, the relative mass of firms, and the relative extent of entry and exit across countries and industries. The free trade propositions concerning these variables were proved using countries' relative factor

\footnotetext{
${ }^{19}$ We emphasize that the productivity effect due to heterogeneous firms is always present, while the range of varieties available for consumption in an industry may rise or fall, depending on changes in average firm size and the allocation of resources to a sector in the trading equilibrium relative to autarky.
} 
endowments and the movement of relative factor rewards following the opening of trade. Since relative factor rewards under costly trade lie in between their autarky and free trade values, the same considerations will apply, only modified to take into account the endogenous movements in the zero-profit productivity cutoff under costly trade. Following the opening of costly trade, the skill-abundant country will see a relative increase in average firm size, the mass of firms and the extent of entry and exit in the skill-intensive industry.

\subsection{Job Creation and Job Destruction}

In the standard Heckscher-Ohlin model, trade liberalization leads to the creation of jobs in the comparative advantage industry and the destruction of jobs in the comparative disadvantage industry. In the heterogeneous-firm framework examined here, we have a similar pattern with respect to net job creation and destruction across industries, although the magnitude of these between-sector reallocations of resources will differ as a result of the emergence of endogenous Ricardian productivity differences at the industry level due to the differential selection of high-productivity firms across industries.

Unlike the standard Heckscher-Ohlin model, there are now important differences between gross and net job creation and destruction. In the comparative disadvantage sector, where there is net job destruction, new jobs are created at high-productivity firms which expand to serve the export market. In the comparative advantage sector, where there is net job creation, existing jobs are destroyed at low productivity firms who exit following the rise in the threshold productivity where zero profits are made.

Our heterogeneous-firm framework is consistent with empirical evidence that gross job creation is large relative to net job creation and with evidence of job destruction across a wide range of industries following trade liberalization (see, for example, Pavcnik 2002). The model implies that the extent of gross job creation and destruction relative to net job creation and destruction will vary systematically across countries, industries and factors of production with patterns of comparative advantage, as well as with other parameters of the model such as sunk entry costs and within-industry productivity distributions.

Within each industry, the change in employment following the opening of costly trade can be decomposed into: (a) the change in employment used in the sunk costs of entry; (b) the change in employment for domestic production due to firm exit or entry; (c) the change in employment for domestic production at continuing firms; (d) the change in employment for the export market due to exit or entry of firms into exporting; and (e) the change in employment for the export market at continuing exporters. 
For example, suppose that the zero profit productivity cutoff within the industry increases from $\varphi_{i}^{\prime}$ to $\varphi_{i}^{\prime \prime}$ and the export productivity cutoff falls from $\varphi_{i x}^{\prime}$ to $\varphi_{i x}^{\prime \prime}$. An industry's change in skilled employment, or net skilled job turnover (NSJT), is:

$$
\begin{aligned}
N S J T_{i}= & \Delta S_{i}=\Delta S_{i}^{e}+\Delta S_{i d}^{p c h a n g e}+\Delta S_{i d}^{p c o n t}+\Delta S_{i x}^{\text {pchange }}+\Delta S_{i x}^{\text {pcont }} \\
= & \Delta S_{i}^{e}+\left(\int_{\varphi_{i}^{\prime}}^{\varphi_{i}^{\prime \prime}} \Delta S_{i d}^{p}(\varphi) d \varphi\right)+\left(\int_{\varphi_{i}^{\prime \prime}}^{\infty} \Delta S_{i d}^{p}(\varphi) d \varphi\right) \\
& +\left(\int_{\varphi_{i}^{\prime \prime}}^{\varphi_{i}^{\prime}} \Delta S_{i x}^{p}(\varphi) d \varphi\right)+\left(\int_{\varphi_{i}^{\prime}}^{\infty} \Delta S_{i x}^{p}(\varphi) d \varphi\right)
\end{aligned}
$$

where $S$ denotes skilled employment; subscripts $i, d$, and $x$ refer to industry, domestic market and export market, respectively; and superscripts $e$, pcont and pchange refer to entry, production at continuing firms and production at entering or exiting firms, respectively.

Labor market clearing implies that net job turnover (net job creation or net job destruction) for a factor in one industry is equal to and the opposite sign of net job turnover for the same factor in the other industry.

The individual terms that make up the total change in skilled employment in equation (34) will typically have different signs, and it is this which makes gross job creation and destruction large relative to their net values. A measure of the industry's gross skilled job turnover (GSJT), which includes both gross job creation and gross job destruction, is:

$$
G S J T_{i}=\left|\Delta S_{i}^{e}\right|+\left|\Delta S_{i d}^{\text {pchange }}\right|+\left|\Delta S_{i d}^{\text {pcont }}\right|+\left|\Delta S_{\text {ix }}^{\text {phange }}\right|+\left|\Delta S_{i x}^{\text {pcont }}\right| .
$$

Taking the ratio of gross job turnover in equation (35) to net job turnover in equation (34) provides a measure of the extent of excess job creation and destruction above and beyond the level required to achieve the between-industry reallocation of resources implied by the opening of costly trade. This excess job creation and destruction is associated with the within-industry reallocations of resources implied by the movements in the zero-profit and exporting productivity cutoffs.

Only in a framework with more than one factor of production and more than one industry can we speak about how changes in relative goods prices affect the income distribution following the opening of trade. In the same way, only with more than one factor of production and more than one industry can we examine the implications of costly trade for job creation and destruction both between and within industries.

The discussion here has focused on job creation and destruction associated with movements between steady-state equilibria following the opening of trade. Trade also has impli- 
cations for steady-state job turnover within countries and industries. Each period, jobs are created and destroyed as a result of labor employed in entry, as a result of labor employed at newly created firms, and as a result of labor employed at newly destroyed firms.

This steady-state job churning is novel relative to the conventional Heckscher-Ohlin model, while the systematic variation in steady-state job churning across countries, industries and factors of production due to comparative advantage contrasts with single-industry models of heterogeneous firms. The implications of costly trade for steady-state job churning mean that our approach links with recent debates about the impact of international trade on job security.

\section{Numerical Solutions}

In this section, we parameterize the costly trade model and solve it numerically. These solutions serve two purposes. First, they provide a visual representation of the equilibria described in the previous sections as well as reinforce the intuition behind them. Second, they allow us to trace out the evolution of variables that cannot be solved for explicitly as trade barriers fall across costly trade equilibria. In particular, we quantify the magnification of comparative advantage and the reallocation of labor between and within industries.

To solve the model numerically, we assume a Pareto distribution for ex ante firm productivity, which is both tractable and provides a good approximation to observed withinindustry productivity distributions:

$$
g(\varphi)=a k^{a} \varphi^{-(a+1)}
$$

where $k>0$ is the minimum value for productivity $(\varphi \geq k)$, and $a>0$ is a shape parameter that determines the skewness of the Pareto distribution. ${ }^{20}$ We assume $a>\sigma-1$ so that $\log$ firm sales have a finite variance.

As described further in the Appendix, we calibrate key parameters of the model to match features of the plant-level U.S. manufacturing data reported in Bernard et al. (2003). To focus on comparative advantage, we assume that all industry parameters except factor intensity $\left(\beta_{i}\right)$ are the same across industries and countries, and that countries $H$ and $F$ have identical populations but different skill abundance $\left(\bar{S}^{i} / \bar{L}^{i}\right)$ ratios of 1200/1000 and $1000 / 1200$, respectively. We consider the implications of moving from autarky to variable

\footnotetext{
${ }^{20}$ See also Helpman et al. (2004) and Ghironi and Melitz (2004) for other studies assuming a Pareto firm productivity distribution.
} 
trade costs ranging from $100 \%$ to $20 \%$ (i.e. from $\tau=2$ to $\tau=1.2$ ). ${ }^{21}$ These assumptions guarantee that outcomes for $F$ are the mirror image of outcomes for $H$; as a result, the figures below refer to outcomes in both countries.

\subsection{Magnification of Comparative Advantage}

Opening to costly trade leads to rises in the zero-profit productivity cutoffs $\left(\varphi_{i}^{*}\right)$ and declines in export productivity cutoffs $\left(\varphi_{i x}^{*}\right)$, as established in Propositions 6 and 7 . These movements are displayed in the top panel of Figure 3, which traces the equilibrium values of the cutoffs for a range of variable trade costs. Note that autarky values in this and later figures are plotted as dots on the right axis, and that variable trade costs are lower moving from right to left along the $x$-axis. Results are displayed for both the comparative advantage industry (solid line) and the comparative disadvantage industry (dashed line).

The declines in the zero-profit productivity cutoffs generate improvements in average productivity in both industries, as shown in the middle panel of Figure 3. The zero-profit cutoff rises faster in the comparative advantage industry, causing that industry to experience larger gains in average productivity. Similarly, the decreases in the export productivity cutoffs lead to a rise in the probability of exporting in both industries. The probability of exporting is higher and increases more rapidly in the comparative advantage industry, as the gap between the industry zero-profit and export productivity cutoffs narrows.

As trade costs fall, specialization according to comparative advantage occurs, because of both endowment differences and endogenous changes in average industry productivity. This specialization is manifest in several dimensions, each of which is displayed in a panel of Figure 4. First (top left), real output $\left(R_{i} / P_{i}\right)$ expands in the comparative advantage industry and contracts in the comparative disadvantage industry. Second (top right), average firm size $\left(\bar{r}_{i}\right)$ grows as existing exporters expand to meet rising foreign demand and additional varieties are exported. This occurs in both industries, but firm size increases fastest in the comparative advantage sector. Third (lower left), because firms expand faster than the industry as a whole, the number of firms in each industry $\left(M_{i}=R_{i} / \bar{r}_{i}\right)$ declines. The decline is smaller in the comparative advantage industry, so the relative mass of firms in that industry rises. Finally (bottom right), owing to the greater export opportunities available in the comparative advantage industry, the mass of entrants rises in that industry and falls in the comparative disadvantage industry. These movements

\footnotetext{
${ }^{21}$ The focus on reductions in trade costs is motivated by the secular declines in tariffs and transportation costs that have occurred in the post-war period.
} 
in relative average firm size, the relative mass of firms and the relative mass of entrants parallel those established in Proposition 3.

The welfare implications of specialization are displayed in Figure 5. The first panel of the figure traces out the overall increase in welfare associated with liberalization, as measured by real aggregate income (which equals the sum of the two lines in the first panel of Figure 4). The second panel of the figure illustrates how welfare gains are distributed across factors by graphing the real wage of each factor and the ratio of the two real wages.

In line with the Stolper-Samuelson Theorem, the reward of the abundant factor rises relative to that of the scarce factor during liberalization. A more striking feature of the panel is that real wages rise for both factors. In this particular parameterization of the model, the traditional Heckscher-Ohlin decline in the real wage of the scarce factor is more than offset by rising productivity and an increase in varieties. Here, as in Helpman and Krugman (1985), the increase in domestic and foreign varieties $\left(M_{1}^{H}+\chi_{1}^{F} M_{1}^{F}\right.$ and $M_{2}^{H}+\chi_{2}^{F} M_{2}^{F}$ for the skill-abundant home country) that become available to consumers through trade raises the welfare of all workers (lower-left panel of Figure 5). More important in this case is the rise in average productivity induced by reallocation across firms. In both industries, rises in average productivity drive down prices and raises welfare for both skilled and unskilled workers. We caution, however, that rising real rewards for both factors depend on endowment differences and other parameters of the model. ${ }^{22}$ However, the productivity effect on prices, and thus on welfare, is always present and serves to offset, if not overturn, the nominal wage fall for the scarce factor.

The final panel of Figure 5 captures the magnification of comparative advantage driven by the differential changes in industry productivity shown in Figure 3. The magnification ratio measures endogenous Ricardian comparative advantage. For skill-abundant home, it is defined as the ratio of home average productivity in the skill-intensive industry to home average productivity in the labor-intensive industry divided by the ratio of foreign average productivity in the two industries (equation (32)). In the Heckscher-Ohlin model, the magnification ratio is constant and equal to unity for all values of $\tau$ because industry productivity does not change. With heterogeneous firms, increases in average industry productivity, which occur differentially across industries and are due to the changing composition of output across firms, cause the magnification ratio to rise as trade costs fall. In our numerical solutions, it rises from unity under autarky to 1.09 when variable trade costs equal 20 percent (i.e. $\tau=1.2$ ).

\footnotetext{
${ }^{22}$ In particular, the number of varieties may actually decrease if the country endowments are too dissimilar.
} 
The changes in average productivity that vary across industries and are displayed in Figure 3 increase average efficiency in the comparative advantage industry. As a result, output in the comparative advantage industry rises by more than it would in the absence of firm heterogeneity. Differential changes in industry productivity also drive up the relative wage of the abundant factor, raise trade flows relative to GDP, cause further declines in the price level, and boost the welfare gains from trade.

\subsection{Job Turnover}

The combination of heterogeneous firms and comparative advantage yields a model in which falling trade costs induce both gross and net job turnover that vary by industry, country, and factor. Jobs are lost in both comparative advantage and disadvantage industries, and job destruction in comparative advantage industries highlights an additional distributional dimension of trade liberalization.

Table 1 summarizes a country's job turnover as variable trade costs decline from autarky to 20 percent. This turnover includes both job creation and job destruction; i.e. each time a worker moves between firms, one job is lost and another is gained. The table is arranged into four panels, each of which reports total, between- and within industry job turnover as a percent of the total labor force (skilled plus unskilled) for a different factor-industry combination.

Between-industry turnover represents transfers of jobs across industries, while withinindustry turnover corresponds to switches of jobs across firms within the same industry. Total job turnover is the sum of the absolute value of between- and within-industry turnover. Due to specialization, between-industry turnover is positive for comparative advantage industries and negative for comparative disadvantage industries. Labor market clearing implies that these between-industry reallocations are equal in magnitude across sectors for a particular factor. As indicated in the table, 14.2 percent of the labor force switches industries as the economy opens to trade, with greater between-industry reallocation among skilled workers.

Unlike traditional endowment-based trade models, our heterogeneous-firm framework generates within-industry job switching. Within-industry turnover is driven by a reallocation of economic activity across firms inside industries as zero-profit productivity cutoffs rise, export productivity cutoffs fall, production for the domestic market declines, and production for the export market expands. Across all factors and industries, within-industry reallocation is substantially larger than between-industry shifts: an additional 21.1 percent 
of the labor force change jobs within sectors. ${ }^{23}$ The degree of intra-industry reallocation is highest (11.0 percent of all workers) for the comparative advantage industry during liberalization. Within-industry job turnover is highest for the abundant factor in the comparative advantage industry (6.7 percent of all workers) and the scarce factor in the comparative disadvantage industry (6.6 percent of the labor force). This result is driven by the interaction of country and industry characteristics: within-industry turnover is highest for the industries and factors that have an affinity for one another in terms of the factor being used relatively intensely by the industry. ${ }^{24}$

Finally, Figure 6 summarizes steady-state factor churning by industry in autarky and with trade costs ranging from 100 percent to 20 percent. This churning is defined as the share of the total labor force engaged in an industry in entry or being used by firms that fail. Steady-state churning rises in the comparative advantage industry for both factors, reflecting the rise in the mass of entrants in that industry as well as changes in the productivity cutoffs and in relative wages as trade costs fall (see Figures 3 to 5).

\section{Conclusions}

This paper combines the new literature on heterogeneous firms in trade with an old tradition of endowment-based comparative advantage. The combination of factor endowment differences across countries, factor intensity differences across industries, and heterogeneous firms within industries is able to simultaneously explain inter-industry trade (countries are net exporters in their industries of comparative advantage), intra-industry trade (even within an industry where a country is a net importer, two-way trade occurs), and selection into export markets (within both net exporting and net importing sectors, some firms export while many others do not).

Our analysis yields a rich set of predictions for the margins along which economies adjust to trade. In general, following the opening of trade, there will be changes in the mass of firms within industries, changes in average firm size, changes in the mass of entering/exiting firms, and changes in industry productivity. The productivity changes will occur whenever there

\footnotetext{
${ }^{23}$ Because each separated worker reflects both one job destroyed and one job created, the share of the labor force changing jobs within industries is half the sum of the within-industry turnovers, $(13.3+7.0+$ $8.7+13.2) / 2=21.1$ ). Similarly, the share of the labor force changing jobs between or within industries is half the sum of the total turnovers noted in the table.

${ }^{24}$ While intra-industry job reallocation is greatest for the abundant factor in the comparative advantage industry, the rise the relative skilled worker wage augments the amount of within-industry reallocation for the scarce factor in both industries.
} 
is selection into export markets, so that opening to trade has differential effects on exporters and non-exporters. More importantly, these adjustments will vary across industries and countries in systematic ways.

The between-industry reallocations of Heckscher-Ohlin theory interact with the withinindustry reallocations of heterogeneous-firm models. When opening to costly trade, comparative advantage industries see the highest probability of exporting, the largest withinindustry reallocations of resources, and the greatest increases in aggregate industry productivity. More attractive export opportunities in comparative advantage industries induce greater entry, a larger reduction in profitability for low productivity firms only serving the domestic market, and a larger increase in the threshold productivity below which firms exit the industry.

Even though technologies are identical across countries, the role of comparative advantage in shaping within-industry reallocation gives rise to endogenous ex post industry productivity differences that reinforce endowment-based comparative advantage. These endogenous Ricardian productivity responses at the industry level have general equilibrium implications for the size of the reallocation of resources between industries, equilibrium relative factor rewards, patterns of trade, and the effects of trade on the income distribution and welfare.

The within-industry reallocations of resources following the opening of trade mean that there is job destruction in both comparative advantage and disadvantage industries. This has potential implications for political economy models that emphasize the role of winners and losers from trade liberalization in determining the structure of protection. Withinindustry reallocation is most intense for the abundant factor used intensively in the comparative advantage industry. Besides reallocations of resources across and within industries following the opening of trade, steady-state rates of job turnover rise in the comparative advantage industry relative to those in the other industry.

Interesting areas for further research include the empirical testing of these theoretical predictions on the role of comparative advantage in industry productivity dynamics and extensions of the theory to introduce additional sources of firm heterogeneity, dynamic firm productivity, and multiple products within industries. While the focus in this paper has been on symmetric reductions of trade costs across industries and countries, the model easily allows the analysis of asymmetric trade cost reductions, as well as variation in the skill intensity of entry, production, and fixed export costs.

More generally, our analysis provides an example of the rich insights to be gained by 
combining microeconomic modelling of firms with general equilibrium analyses of trade. It points to fruitful further research placing individual firm behavior at the center of economies' adjustment to trade. 


\section{References}

Anderson, James and Eric van Wincoop, (2004) 'Trade Costs', National Bureau of Economic Research working paper \# 10480.

Bartelsman, Eric and Mark Doms, (2000) 'Understanding Productivity: Lessons from Longitudinal Microdata', Journal of Economic Literature, XXXVIII, 569-94.

Bernard, Andrew B., Eaton, Jonathan, Jensen, J. Bradford and Samuel S. Kortum, (2003) 'Plants and Productivity in International Trade', American Economic Review, Vol. 93, No. 4, September, 1268-1290.

Bernard, Andrew B. and J. Bradford Jensen (1995) 'Exporters, Jobs, and Wages in US Manufacturing: 1976-87', Brookings Papers on Economic Activity: Microeconomics, 67112 .

Bernard, Andrew B. and J. Bradford Jensen (1999) 'Exceptional Exporter Performance: Cause, Effect, or Both?', Journal of International Economics, 47(1), 1-25.

Bernard, Andrew B., and J. Bradford Jensen, (2004) 'Why Some Firms Export', Review of Economics and Statistics, 86(2): 561-569.

Bernard, Andrew B., J. Bradford Jensen and Peter K. Schott. (2004) 'Survival of the Best Fit: Exposure to Low Wage Countries and the (Uneven) Growth of U.S. Manufacturing Plants'. Tuck School of Business mimeo, revision of NBER Working Paper \# 9170.

Clerides, Sofronis, Lach, Saul and James Tybout, (1998) 'Is Learning by Exporting Important? Micro-dynamic Evidence from Columbia, Mexico and Morocco', Quarterly Journal of Economics, 113, 903-47.

Davis, Steven J and John Haltiwanger. (1991) 'Wage Dispersion between and within U.S. Manufacturing Plants, 1963-86', Brookings Papers on Economic Activity, Microeconomics, $115-80$.

Dunne, Timothy, Mark J. Roberts, and Larry Samuelson. (1989) 'The Growth and Failure of U.S. Manufacturing Plants', Quarterly Journal of Economics, Vol. 104, No. 4 , pp. 671-698.

Dixit, Avinash and Victor Norman, (1980) The Theory of International Trade, Cambridge University Press: Cambridge UK. 
Flam, Harry and Elhanan Helpman, (1987) 'Industrial Policy Under Monopolistic Competition', Journal of International Economics, 22, 79-102.

Ghironi, Fabio and Marc J. Melitz (2004) 'International Trade and Macroeconomic Dynamics with Heterogeneous Firms' National Bureau of Economic Research working paper \# 10540 .

Helpman, Elhanan and Paul Krugman, (1985) Market Structure and Foreign Trade: Increasing Returns, Imperfect Competition and the International Economy, MIT Press, Cambridge, MA.

Helpman, Elhanan, Melitz, Marc J. and Stephen R. Yeaple (2004) 'Export Versus FDI with Heterogeneous Firms', American Economic Review, 94(1), 300-16.

Hopenhayn, Hugo. (1992) 'Entry, Exit, and Firm Dynamics in Long Run Equilibrium', Econometrica, 60(5), 1127-1150.

Hummels, David (2001) 'Toward a Geography of Trade Costs', Purdue University, mimeograph.

Jovanovic, Boyan. (1982) 'Selection and the Evolution of Industry', Econometrica, vol. 50, no. 3, May, 649-70.

Markusen, James R. and Venables, Anthony J. (2000) 'The Theory of Endowment, Intraindustry and Multi-national Trade', Journal of International Economics, 52, 209-34.

Melitz, Marc J. (2003) 'The Impact of Trade on Intra-Industry Reallocations and Aggregate Industry Productivity', Econometrica, Vol. 71, November 2003, pp. 1695-1725.

Melitz, Marc J. and Gianmarco I. P. Ottaviano,(2003) 'Market Size, Trade, and Productivity', Harvard University, mimeograph.

Pavcnik, N (2002) 'Trade Liberalization, Exit, and Productivity Improvement: Evidence from Chilean Plants', Review of Economic Studies, 69(1), 245-76.

Roberts, Mark J. and James Tybout, (1997a) 'The Decision to Export in Colombia: An Empirical Model of Entry with Sunk Costs', American Economic Review, 87(4), 545-64.

Roberts, Mark J. and James Tybout, (1997b) What Makes Exports Boom?, The World Bank. 
Samuelson, Paul A. "International Factor Price Equalization Once Again." Economic Journal, June 1949, 59(234), pp. 181-97.

Schott, Peter K. (2004) 'Across-Product versus Within-Product Specialization in International Trade', Quarterly Journal of Economics, Vol 119, No. 2. 647-678.

\section{A Appendix}

\section{A1. Proof of Proposition 1}

Proof. (a) Begin with the existence of a unique integrated equilibrium.

Choose the skilled wage as numeraire, so $w_{S}=1$.

From the free entry condition (13), $V_{i} \rightarrow \infty$ as $\varphi_{i}^{*} \rightarrow 0 ; V_{i} \rightarrow 0$ as $\varphi_{i}^{*} \rightarrow \infty$; and $V_{i}$ is monotonically decreasing in $\varphi_{i}^{*}$. Thus, equation (13) defines a unique equilibrium value of the zero-profit productivity cutoff, $\hat{\varphi}_{i}^{*}$, as a function of parameters.

From equation (12), $\varphi_{i}^{*}$ uniquely determines weighted average productivity, $\widetilde{\varphi}_{i}\left(\varphi_{i}^{*}\right)$. Combining $\bar{r}_{i}=r_{i}\left(\tilde{\varphi}_{i}\right)=\left(\tilde{\varphi}_{i} / \varphi_{i}^{*}\right)^{\sigma-1} r_{i}\left(\varphi_{i}^{*}\right)$ with the zero-profit cutoff condition (8), average revenue and profitability may be expressed as functions of $\varphi_{i}^{*}$ and factor rewards alone:

$$
\begin{aligned}
& \bar{r}_{i}=r_{i}\left(\widetilde{\varphi}_{i}\right)=\left(\frac{\widetilde{\varphi}_{i}\left(\varphi_{i}^{*}\right)}{\varphi_{i}^{*}}\right)^{\sigma-1} \sigma f_{i}\left(w_{S}\right)^{\beta_{i}}\left(w_{L}\right)^{1-\beta_{i}} \\
& \bar{\pi}_{i}=\pi_{i}\left(\widetilde{\varphi}_{i}\right)=\left[\left(\frac{\widetilde{\varphi}_{i}\left(\varphi_{i}^{*}\right)}{\varphi_{i}^{*}}\right)^{\sigma-1}-1\right] f_{i}\left(w_{S}\right)^{\beta_{i}}\left(w_{L}\right)^{1-\beta_{i}} .
\end{aligned}
$$

In each sector, the total value of payments to labor used in production equals total revenue minus total profits:

$$
w_{S} S_{i}^{p}+w_{L} L_{i}^{p}=R_{i}-\Pi_{i}
$$

while, combining free entry (11) and steady-state stability (14), the total value of payments to labor used in entry equals total profits:

$$
\Pi_{i}=M_{i} \bar{\pi}_{i}=M_{e i} f_{e i}\left(w_{S}\right)^{\beta_{1}}\left(w_{L}\right)^{1-\beta_{1}}=w_{S} S_{i}^{e}+w_{L} L_{i}^{e} .
$$

Thus, total payments to labor in each sector equal total revenue:

$$
w_{S} S_{i}+w_{L} L_{i}=R_{i}
$$

where $S_{i}=S_{i}^{p}+S_{i}^{e}$ and $L_{i}=L_{i}^{p}+L_{i}^{e}$. Since this is true for both sectors, aggregate revenue equals aggregate income:

$$
w_{S} \bar{S}+w_{L} \bar{L}=R .
$$


Since production technologies in each sector are Cobb-Douglas with the same factor intensities for production and entry, payments to skilled and unskilled labor are a constant share of total industry revenue, yielding the following equilibrium labor demands:

$$
S_{i}=\frac{\beta_{i} R_{i}}{w_{S}}, \quad L_{i}=\frac{\left(1-\beta_{i}\right) R_{i}}{w_{L}}
$$

Combining these expressions with labor market clearing, and using the fact that the representative consumer allocates constant shares of expenditure $\{\alpha,(1-\alpha)\}$ to the two sectors, we obtain the integrated equilibrium labor allocation:

$$
\begin{aligned}
S_{1} & =\left(\frac{\beta_{1} \alpha}{\beta_{1} \alpha+\beta_{2}(1-\alpha)}\right) \bar{S}, \quad S_{2}=\left(\frac{\beta_{2}(1-\alpha)}{\beta_{1} \alpha+\beta_{2}(1-\alpha)}\right) \bar{S} \\
L_{1} & =\left(\frac{\left(1-\beta_{1}\right) \alpha}{\left(1-\beta_{1}\right) \alpha+\left(1-\beta_{2}\right)(1-\alpha)}\right) \bar{L} \\
L_{2} & =\left(\frac{\left(1-\beta_{2}\right)(1-\alpha)}{\left(1-\beta_{1}\right) \alpha+\left(1-\beta_{2}\right)(1-\alpha)}\right) \bar{L} .
\end{aligned}
$$

Substituting equilibrium employment into the expression for unskilled labor demand, and simplifying using equilibrium consumer expenditure shares and our choice of numeraire, yields the integrated equilibrium unskilled wage:

$$
w_{L}=\left(\frac{\bar{S}}{\bar{L}}\right)\left(\frac{1-\beta_{2}-\alpha \beta_{1}+\alpha \beta_{2}}{\beta_{2}+\alpha \beta_{1}-\alpha \beta_{2}}\right)
$$

The integrated equilibrium vector is $\left\{\varphi_{1}^{*}, \varphi_{2}^{*}, P_{1}, P_{2}, R, p_{1}(\varphi), p_{2}(\varphi), w_{S}, w_{L}\right\}$. We have solved for $\left\{\varphi_{1}^{*}, \varphi_{2}^{*}\right\}$ and $\left\{w_{S}, w_{L}\right\} . \quad\left\{p_{1}(\varphi), p_{2}(\varphi)\right\}$ follow immediately from the pricing rule (4) and equilibrium wages. $\{R\}$ follows from equation (41) and equilibrium wages. $\left\{P_{1}, P_{2}\right\}$ may be determined from the analogue of equation (15) for the integrated world economy: $P_{i}=M_{i}^{1 /(1-\sigma)} p_{i}\left(\tilde{\varphi}_{i}\right)$, where $\tilde{\varphi}_{i}$ is uniquely determined by $\varphi_{i}^{*}$ and $M_{i}=R_{i} / \bar{r}_{i}$. From equation (37), $\bar{r}_{i}$ is determined by $\varphi_{i}^{*}$ and wages for which we have solved. From equation (40), $R_{i}$ is determined by wages and labor allocations for which we have also solved. We have thus fully characterized the integrated equilibrium vector.

(b) Now establish the existence of a FPE equilibrium which replicates the integrated equilibrium resource allocation.

FPE and our choice of the skilled wage in one country as numeraire implies:

$$
w_{S}^{H}=w_{S}^{F}=w_{S}=1, \quad w_{L}^{H}=w_{L}^{F}=w_{L} .
$$


Cost minimization implies the same equilibrium factor intensities in the two countries:

$$
\frac{S_{i}^{H}}{L_{i}^{H}}=\frac{S_{i}^{F}}{L_{i}^{F}}=\frac{\beta_{i}}{1-\beta_{i}} \frac{w_{L}}{w_{S}}=\frac{\beta_{i}}{1-\beta_{i}} w_{L}
$$

The factor market clearing conditions in each country $k \in\{H, F\}$ may be expressed as follows:

$$
\begin{aligned}
\lambda_{L 1}^{k}\left(\frac{S_{1}^{k}}{L_{1}^{k}}\right)+\left(1-\lambda_{L 1}^{k}\right)\left(\frac{S_{2}^{k}}{L_{2}^{k}}\right) & =\frac{\bar{S}^{k}}{\bar{L}^{k}}, & \lambda_{L i}^{k} \equiv \frac{L_{i}^{k}}{\bar{L}^{k}} \\
\lambda_{S 1}^{k}\left(\frac{L_{1}^{k}}{S_{1}^{k}}\right)+\left(1-\lambda_{S 1}^{k}\right) \frac{L_{2}^{k}}{S_{2}^{k}} & =\frac{\bar{L}^{k}}{\bar{S}^{k}}, & \lambda_{\mathrm{Si}}^{k} \equiv \frac{S_{i}^{k}}{\bar{S}^{k}}
\end{aligned}
$$

Substituting for equilibrium factor intensities in the above and rearranging yields the free trade equilibrium labor allocations in each country as a function of endowments and the common unskilled relative wage for which we solve below:

$$
\begin{aligned}
L_{1}^{k} & =\frac{\frac{1}{w_{L}^{k}} \bar{S}^{k}-\left(\frac{\beta_{2}}{1-\beta_{2}}\right) \bar{L}^{k}}{\left(\frac{\beta_{1}}{1-\beta_{1}}\right)-\left(\frac{\beta_{2}}{1-\beta_{2}}\right)}, \quad L_{2}^{k}=\frac{\left(\frac{\beta_{1}}{1-\beta_{1}}\right) \bar{L}^{k}-\frac{1}{w_{L}} \bar{S}^{k}}{\left(\frac{\beta_{1}}{1-\beta_{1}}\right)-\left(\frac{\beta_{2}}{1-\beta_{2}}\right)} \\
S_{1}^{k} & =\frac{\left(\frac{\beta_{1}}{1-\beta_{1}}\right) \bar{S}^{k}-\left(\frac{\beta_{1}}{1-\beta_{1}}\right)\left(\frac{\beta_{2}}{1-\beta_{2}}\right) w_{L} \bar{L}^{k}}{\left(\frac{\beta_{1}}{1-\beta_{1}}\right)-\left(\frac{\beta_{2}}{1-\beta_{2}}\right)} \\
S_{2}^{k} & =\frac{\left(\frac{\beta_{1}}{1-\beta_{1}}\right)\left(\frac{\beta_{2}}{1-\beta_{2}}\right) w_{L} \bar{L}^{k}-\left(\frac{\beta_{2}}{1-\beta_{2}}\right) \bar{S}^{k}}{\left(\frac{\beta_{1}}{1-\beta_{1}}\right)-\left(\frac{\beta_{2}}{1-\beta_{2}}\right)}
\end{aligned}
$$

Applying the same arguments as in the integrated equilibrium, aggregate income in each country equals aggregate revenue:

$$
R^{k}=\bar{S}^{k}+w_{L} \bar{L}^{k}
$$

In both countries, total industry payments to unskilled labor are a constant share $\left(1-\beta_{i}\right)$ of total industry revenue, while world expenditure on a good equals a constant share of world revenue:

$$
w_{L}\left(L_{1}^{H}+L_{1}^{F}\right)=\left(1-\beta_{1}\right) \alpha\left[\left(\bar{S}^{H}+\bar{S}^{F}\right)+w_{L}\left(\bar{L}^{H}+\bar{L}^{F}\right)\right] .
$$

Substituting for free trade equilibrium employment levels $\left\{L_{1}^{H}, L_{1}^{F}\right\}$ and rearranging yields the equilibrium unskilled wage, which equals the value for the integrated world economy in 
equation (45).

The FPE set is characterized by the requirement that both countries' relative endowments of skilled and unskilled workers lie in between the integrated equilibrium factor intensities of the two sectors:

$$
\left(\frac{\beta_{1}}{1-\beta_{1}}\right) \widehat{w}_{L}^{I E}>\frac{\bar{S}^{H}}{\bar{L}^{H}}>\frac{\bar{S}^{F}}{\bar{L}^{F}}>\left(\frac{\beta_{2}}{1-\beta_{2}}\right) \widehat{w}_{L}^{I E}
$$

where the superscript $I E$ indicates an integrated equilibrium value.

The free trade equilibrium is referenced by the vector $\left\{\varphi_{1}^{* k}, \varphi_{2}^{* k}, P_{1}^{k}, P_{2}^{k}, R^{k}, p_{1}^{k}(\varphi), p_{2}^{k}(\varphi), w_{S}^{k}, w_{L}^{k}\right\}$ for each country $k \in\{H, F\}$.

We have already solved for $\left\{w_{S}^{H}=w_{S}^{F}=1, w_{L}^{H}=w_{L}^{F}\right\} . \quad\left\{p_{1}^{H}(\varphi)=p_{1}^{F}(\varphi), p_{2}^{H}(\varphi)=p_{2}^{F}(\varphi)\right\}$ follow immediately from the pricing rule (4) and equilibrium wages. $\left\{R^{k}\right\}$ follows from equation (51) and equilibrium wages. $\left\{\varphi_{1}^{* H}=\varphi_{1}^{* F}, \varphi_{2}^{* H}=\varphi_{2}^{* H}\right\}$ are determined by the free entry condition alone (equation (13)). $\left\{P_{1}^{H}=P_{1}^{F}, P_{2}^{H}=P_{2}^{F}\right\}$ are determined from equation (15), where $\tilde{\varphi}_{i}$ is uniquely determined by $\varphi_{i}^{*}$ and $M_{i}^{k}=R_{i}^{k} / \bar{r}_{i}^{k}$. From equation (37), $\bar{r}_{i}^{H}=\bar{r}_{i}^{F}$ is determined by equilibrium $\varphi_{i}^{* k}$ and factor rewards for which we have solved. From equation (40), $R_{i}^{k}$ is determined by wages and labor allocations in each country for which we have also solved. We have thus completed our characterization of the FPE equilibrium vector.

We have already established that, for country factor endowments within the FPE set, free trade equilibrium wages equal their value in the integrated equilibrium. Since the free entry condition is the same in the two countries and a function of parameters alone, the free trade zero-profit cutoff productivities also equal their integrated equilibrium values. Thus, $\left\{\varphi_{1}^{* k}\right.$,

$\left.\varphi_{2}^{* k}, P_{1}^{k}, P_{2}^{k}, p_{1}^{k}(\varphi), p_{2}^{k}(\varphi), w_{S}^{k}, w_{L}^{k}\right\}$ are the same as in integrated equilibrium. Aggregate revenue, industry revenue, the mass of firms, and labor allocations will vary across countries in the free trade equilibrium. However, their sum across countries equals the values in the integrated equilibrium.

\section{A2. Proof of Proposition 2}

Proof. (a) In the FPE equilibrium, $S_{1}^{H} / L_{1}^{H}=S_{1}^{F} / L_{1}^{F}$ and $S_{2}^{H} / L_{2}^{H}=S_{2}^{F} / L_{2}^{F}$. Industry 1 is relatively skill intensive: $S_{1}^{k} / L_{1}^{k}>S_{2}^{k} / L_{2}^{k}$ for $k \in\{H, F\}$. Country $H$ is relatively skill abundant: $S^{H} / L^{H}>S^{F} / L^{F}$. From equation (48), it follows immediately that $\lambda_{L 1}^{H}>\lambda_{L 1}^{F}$ and $\lambda_{S 1}^{H}>\lambda_{S 1}^{F}$.

(b) The FPE equilibrium relative wage equals the value for the integrated world economy. Choose a country's skilled wage for the numeraire, $w_{S}^{H}=w_{S}^{F}=1$. Compare the closed 
economy equilibrium relative unskilled wage in equation (45) for an individual country and the integrated world economy. It follows immediately that $\bar{S}^{H} / \bar{L}^{H}>\left(\bar{S}^{H}+\bar{S}^{F}\right) /\left(\bar{L}^{H}+\bar{L}^{F}\right)$ implies $w_{L}^{A}>w_{L}^{F T}$, where the superscripts $A$ and FT indicate autarky and free trade respectively. Therefore, in the move from autarky to free trade, the unskilled relative wage, $w_{L}$, will fall in a skill-abundant country and rise in a labor-abundant country.

From (42) and (48), cost minimization and factor market clearing imply:

$$
\begin{aligned}
\lambda_{L 1}^{k}\left(\frac{\beta_{1}}{1-\beta_{1}} w_{L}\right)+\left(1-\lambda_{L 1}^{k}\right)\left(\frac{\beta_{2}}{1-\beta_{2}} w_{L}\right) & =\frac{\bar{S}^{k}}{\bar{L}^{k}} \\
\lambda_{S 1}^{k}\left(\frac{1-\beta_{1}}{\beta_{1}} \frac{1}{w_{L}}\right)+\left(1-\lambda_{S 1}^{k}\right)\left(\frac{1-\beta_{2}}{\beta_{2}} \frac{1}{w_{L}}\right) & =\frac{\bar{L}^{k}}{\bar{S}^{k}}
\end{aligned}
$$

where we have used $w_{S}=1$. In equation (54), $w_{L}^{F T}<w_{L}^{A}$ implies $\lambda_{L 1}^{F T}>\lambda_{L 1}^{A}$ and $\lambda_{S 1}^{F T}>\lambda_{S 1}^{A}$, since $\beta_{1}>\beta_{2}$. Thus, following the opening of trade, the skill-abundant country will devote an increased share of its skilled and unskilled labor to the skill-intensive industry, and the labor-abundant country will devote an increased share of its skilled and unskilled labor to the labor-intensive industry.

(c) The effect of opening to trade on relative factor rewards was established in the proof of (b). The relative skilled wage rises in the skill-abundant country and falls in the laborabundant country, which establishes the Proposition.

\section{A3. Proof of Proposition 3}

Proof. (a) A common value for the zero-profit productivity cutoff within industries across countries follows immediately from the assumption of identical technologies and equation (13) which uniquely pins down $\varphi_{i}^{*}$ as a function of model parameters alone. A common $\varphi_{i}^{*}$ implies, from equation (12), the same value of $\widetilde{\varphi}_{i}$ within industries across countries.

(b) Combining common values of $\varphi_{i}^{*}$ and $\widetilde{\varphi}_{i}$ with factor price equalization implies, from equation (37), that the two countries have the same average firm size within an industry, $\bar{r}_{i}$.

(c) Since $M_{i}^{k}=R_{i}^{k} / \bar{r}_{i}^{k}$ and $R_{i}^{k}=w_{L}^{k} L_{i}^{k}+w_{S}^{k} S_{i}^{k}$ for country $k \in\{H, F\}$, we have:

$$
\frac{M_{1}^{k}}{M_{2}^{k}}=\left[\frac{w_{L} L_{1}^{k}+S_{1}^{k}}{w_{L} L_{2}^{k}+S_{2}^{k}}\right] \frac{\bar{r}_{2}^{k}}{\bar{r}_{1}^{k}}
$$

where, with factor price equalization, $w_{L}^{k}=w_{L}$, and $w_{S}^{k}=w_{S}=1$. Substituting for equilibrium labor allocations from equations (49) and (50), noting that average revenue can 
be expressed as in equation (37), and simplifying terms we obtain:

$$
\frac{M_{1}^{k}}{M_{2}^{k}}=\left[\frac{\left(1-\beta_{2}\right) \frac{\bar{S}^{k}}{\bar{L}^{k}}-\beta_{2} w_{L}}{\beta_{1} w_{L}-\left(1-\beta_{1}\right) \frac{\bar{S}^{k}}{\bar{L}^{k}}}\right]\left(\frac{\widetilde{\varphi}_{2} / \varphi_{2}^{*}}{\widetilde{\varphi}_{1} / \varphi_{1}^{*}}\right)^{\sigma-1}\left(\frac{f_{2}}{f_{1}}\right)\left(\frac{w_{L}}{1}\right)^{\beta_{1}-\beta_{2}}
$$

where, from equations (13) and (12), $\varphi_{i}^{*}$ and $\widetilde{\varphi}_{i}$ are determined by model parameters and are the same across countries. From equation (56), $S^{H} / L^{H}>S^{F} / L^{H}$ implies $M_{1}^{H} / M_{2}^{H}>$ $M_{1}^{F} / M_{2}^{F}$.

(d) From the steady-state stability conditions (14):

$$
\frac{M_{e 1}^{k}}{M_{e 2}^{k}}=\frac{\left[1-G\left(\varphi_{2}^{*}\right)\right]}{\left[1-G\left(\varphi_{1}^{*}\right)\right]} \frac{M_{1}^{k}}{M_{2}^{k}}
$$

Since $\varphi_{i}^{*}$ is the same within industries across countries, $M_{1}^{H} / M_{2}^{H}>M_{1}^{F} / M_{2}^{F}$ implies $M_{e 1}^{H} / M_{e 2}^{H}>M_{e 1}^{F} / M_{e 2}^{F}$.

\section{A4. Proof of Proposition 4}

Proof. (a) The zero-profit productivity cutoff remains unchanged in the move from autarky to free trade because the free entry condition (13) uniquely pins down $\varphi_{i}^{* k}$ as a function of model parameters alone. With the zero-profit cutoff productivity unchanged, weighted average productivity, $\widetilde{\varphi}_{i}^{k}$, in equation (12) will also remain the same.

(b) From equation (37), relative firm average size in the two sectors is:

$$
\frac{\bar{r}_{1}^{k}}{\bar{r}_{2}^{k}}=\left(\frac{\widetilde{\varphi}_{1}^{k} / \varphi_{1}^{* k}}{\widetilde{\varphi}_{2}^{k} / \varphi_{2}^{* k}}\right)^{\sigma-1}\left(\frac{f_{1}}{f_{2}}\right)\left(\frac{w_{S}^{k}}{w_{L}^{k}}\right)^{\beta_{1}-\beta_{2}}
$$

where $\varphi_{i}^{*}$ remains unchanged in the move from autarky to free trade and hence, from equation (12), so does $\widetilde{\varphi}_{i}$. In the skill-abundant country, the relative skilled wage rises following the opening of trade, increasing relative average firm size in the skill-intensive industry, since $\beta_{1}>\beta_{2}$. The converse is true for the labor-abundant country, where average firm size rises in the labor-intensive industry.

(c) The relative mass of firms in the two sectors may be determined from equation (56). Moving from autarky to free trade, the relative unskilled wage falls in the skill-abundant country. Taking logarithms and totally differentiating with respective to the relative un- 
skilled wage in equation (56), and rearranging, it can be shown that:

$$
\begin{aligned}
& \frac{d \log \left(M_{1}^{k} / M_{2}^{k}\right)}{d\left(w_{L}^{k} / w_{S}^{k}\right)} \stackrel{\operatorname{sign}}{=}-\beta_{2}\left(1-\beta_{2}\right)\left[\frac{w_{L}^{k}}{w_{S}^{k}}+\frac{\bar{S}^{k}}{L^{k}}\right] \underbrace{\left[\beta_{1} \frac{w_{L}^{k}}{w_{S}^{k}}-\left(1-\beta_{1}\right) \frac{\bar{S}^{k}}{\bar{L}^{k}}\right]}_{\bar{S}^{k}}<0 \\
& -\beta_{1}\left(1-\beta_{1}\right)\left[\frac{w_{L}^{k}}{w_{S}^{k}}+\frac{\bar{S}^{k}}{L^{k}}\right] \underbrace{\left[\left(1-\beta_{2}\right) \frac{\bar{S}^{k}}{\bar{L}^{k}}-\beta_{2} \frac{w_{L}^{k}}{w_{S}^{k}}\right]}_{+ \text {ve }}<0
\end{aligned}
$$

Thus, the relative mass of firms in the skill-intensive industry rises in the skill-abundant country. The converse is true in the labor-abundant country, where the relative unskilled wage increases, and the relative mass of firms in the labor-intensive industry rises.

(d) The relative mass of entrants in the two sectors may be determined from equation (57). Since the zero-profit productivity cutoff is unchanged in the move from autarky to free trade, the relative mass of entrants will move proportionately with the relative mass of firms, which establishes the Proposition.

\section{A5. Proof of Proposition 5}

Proof. We choose the skilled wage in one country as numeraire, $w_{S}^{H}=1$.

Suppose that the equilibrium wage vector $\left\{1, w_{L}^{H}, w_{S}^{F}, w_{L}^{F}\right\}$ is known.

The free trade equilibrium allocations of skilled and unskilled labor in equations (49) and (50) were determined using labor market clearing (equation (17)) and equilibrium industry factor intensities (equation (47)). The expressions for the costly trade equilibrium allocations of skilled and unskilled labor are the same, except that the relative unskilled wage will now generally vary across countries, so that terms in what was previously the common unskilled wage, $w_{L}$, need to be replaced with country-specific values for the relative unskilled wage, $w_{L}^{k} / w_{S}^{k}$ for $k \in\{H, F\}$.

Using the costly trade analogues of equations (49) and (50), the wage vector uniquely pins down equilibrium labor allocations in home and foreign: $\left\{L_{1}^{H}, L_{2}^{H}, L_{1}^{F}, L_{2}^{F}, S_{1}^{H}, S_{2}^{H}, S_{1}^{F}\right.$, $\left.S_{2}^{F}\right\}$. These equilibrium allocations now include labor used in entry, production and exporting: $L_{i}^{k}=L_{i}^{k p}+L_{i}^{k e}+L_{i}^{k x}$ and $S_{i}^{k}=S_{i}^{k p}+S_{i}^{k e}+S_{i}^{k x}$.

Following the same line of reasoning as in the proof of Proposition 1, it may be shown that total industry payments to labor used in production, entry and exporting equal total industry revenue:

$$
R_{1}^{k}=w_{S}^{k} S_{1}^{k}+w_{L}^{k} L_{1}^{k}, \quad R_{2}^{k}=w_{S}^{k} S_{2}^{k}+w_{L}^{k} L_{2}^{k}
$$


Thus, the wage vector and equilibrium labor allocations uniquely pin down total industry revenue $\left\{R_{1}^{H}, R_{2}^{H}, R_{1}^{F}, R_{2}^{F}\right\}$ and hence each country's aggregate revenue $\left\{R^{H}, R^{F}\right\}$.

The pricing rule (19) determines equilibrium variety prices in the domestic and export markets for each country $\left\{p_{1 d}^{H}(\varphi), p_{1 x}^{H}(\varphi), p_{2 d}^{H}(\varphi), p_{2 x}^{H}(\varphi), p_{1 d}^{F}(\varphi), p_{1 x}^{F}(\varphi), p_{2 d}^{F}(\varphi), p_{2 x}^{F}(\varphi)\right\}$ as a function of the wage vector.

With wages, variety prices, total industry revenue, and aggregate revenue known, the equilibrium zero-profit cutoff productivities $\left\{\varphi_{1}^{* k}, \varphi_{2}^{* k}\right\}$, the exporting-cutoff productivities $\left\{\varphi_{1 x}^{* k}\right.$, $\left.\varphi_{2 x}^{* k}\right\}$, and price indices $\left\{P_{1}^{k}, P_{2}^{k}\right\}$ are the solution to the system of six simultaneous equations in each country $k$ defined by (28), (25) and (29) for the two industries. In solving this system of six simultaneous equations in each country, we substitute out for the equilibrium mass of firms, $M_{i}^{k}=R_{i}^{k} / \bar{r}_{i}^{k}$, probability of exporting, $\chi_{i}^{k}=\frac{\left[1-G\left(\varphi_{i x}^{* k}\right)\right]}{\left[1-G\left(\varphi_{i}^{* k}\right)\right]}$, and average firm revenue, $\bar{r}_{i}^{k}=\left(\frac{\widetilde{\varphi}_{i}^{k}\left(\varphi_{i}^{* k}\right)}{\varphi_{i}^{* k}}\right)^{\sigma-1} \sigma f_{i}\left(w_{S}^{k}\right)^{\beta_{i}}\left(w_{L}^{k}\right)^{1-\beta_{i}}$, using the fact that these are functions of elements of the six unknowns $\left\{\varphi_{1}^{* k}, \varphi_{2}^{* k}, \varphi_{1 x}^{* k}, \varphi_{2 x}^{* k}, P_{1}^{k}, P_{2}^{k}\right\}$ as well as the known wage vector and equilibrium industry revenue for which we have already solved.

Thus, given the wage vector $\left\{1, w_{L}^{H}, w_{S}^{F}, w_{L}^{F}\right\}$, we have solved for all other elements of the equilibrium vector $\left\{\varphi_{1}^{* k}, \varphi_{2}^{* k}, \varphi_{1 x}^{* k}, \varphi_{2 x}^{* k}, P_{1}^{k}, P_{2}^{k}, p_{1}^{k}(\varphi), p_{2}^{k}(\varphi), p_{1 x}^{k}(\varphi), p_{2 x}^{k}(\varphi), R^{k}\right\}$ for $k \in\{H, F\}$.

The equilibrium wage vector itself is pinned down by the requirement that the value of total industry revenue, $R_{i}^{k}=w_{S}^{k} S_{i}^{k}+w_{L}^{k} L_{i}^{k}$, equals the sum of domestic and foreign expenditure on domestic varieties (equation (30) for each country and industry).

\section{A6. Proof of Proposition 6}

Proof. (a) Under autarky, the free entry condition is given by (13), which equals the value for the integrated world economy (a closed economy). Under costly trade, the free entry condition becomes (28), where the relationship between the productivity cutoffs is governed by equation (25), so that $\varphi_{i x}^{* k}=\Lambda_{i}^{k} \varphi_{i}^{*}$. The expected value of entry, $V_{i}^{k}$, in equation (28) equals its value in the closed economy (equation (13)), plus a positive term reflecting the probability of drawing a productivity high enough to export. Since, using equation (25), $V_{i}^{k}$ is monotonically decreasing in $\varphi_{i}^{* k}$, the costly trade equilibrium must be characterized by a higher value of $\varphi_{i}^{* k}$ than under autarky, in order for $V_{i}^{k}$ to equal the sunk entry cost $f_{\text {ei }}$.

(b) The additional positive term in the costly trade free entry condition (28) will be larger, and hence the increase in $\varphi_{i}^{* k}$ will be greater, when $\Lambda_{i}^{k}$ is smaller (when $\varphi_{i x}^{* k}$ is close to 
$\left.\varphi_{i}^{* k}\right)$. The second part of the proposition follows immediately from the definition of $\Lambda_{i}^{k}$ in equation (25).

(c) The probability of exporting, $\chi_{i}^{k}=\left[1-G\left(\Lambda_{i}^{k} \varphi_{i}^{* k}\right)\right] /\left[1-G\left(\varphi_{i}^{* k}\right)\right]$, is monotonically decreasing in $\Lambda_{i}^{k}$. Hence, the final part of the proposition also follows immediately from the definition of $\Lambda_{i}^{k}$ in equation (25).

\section{A7. Proof of Proposition 7}

Proof. (a) At the free trade equilibrium, the relative price indices of the two sectors are the same in the two countries and are determined according to equation (15). Under autarky, the relative price indices generally differ across countries $k$ and are given by:

$$
\frac{P_{1}^{k}}{P_{2}^{k}}=\left(\frac{M_{1}^{k}}{M_{2}^{k}}\right)^{\frac{1}{1-\sigma}} \frac{p_{1}^{k}\left(\widetilde{\varphi}_{1}^{k}\right)}{p_{2}^{k}\left(\widetilde{\varphi}_{2}^{k}\right)},
$$

where the closed economy relative mass of firms, $M_{i}^{k} / M_{2}^{k}$, may be determined following a similar line of reasoning as under free trade (equation (56)). The mass of firms $M_{i}^{k}=R_{i}^{k} / \bar{r}_{i}^{k}$, equilibrium average revenue is given by equation (37), while, under autarky, $R_{i}^{k}=\alpha_{i} R^{k}$. Substituting for the relative mass of firms in the above, and simplifying using the pricing rule (19), the autarky relative price index becomes:

$$
\frac{P_{1}^{k}}{P_{2}^{k}}=\left(\frac{\alpha}{1-\alpha}\right) \frac{\varphi_{2}^{* k}}{\varphi_{1}^{* k}}\left(\frac{f_{2}}{f_{1}}\right)^{\frac{1}{1-\sigma}}\left(\frac{w_{L}^{k}}{w_{S}^{k}}\right)^{\frac{\sigma\left(\beta_{1}-\beta_{2}\right)}{1-\sigma}}
$$

To make comparisons across the two countries under autarky, we require consistent units of measurement and we choose skilled labor as the numeraire in each country, $w_{S}^{H}=1$ and

$w_{S}^{F}=1$. The closed economy relative unskilled wage is given by equation (45), substituting a country's relative endowments for world relative endowments (exploiting the fact that the integrated world economy is closed). From equation (45), the closed economy with a larger relative supply of skilled labor is characterized by a higher relative wage of unskilled workers, $w_{L}^{k}$.

In equation (61), $\beta_{1}>\beta_{2}$ and $\sigma>1$, while identical technologies implies $\varphi_{i}^{* H}=\varphi_{i}^{* F}$. Hence, the higher relative wage of unskilled workers in the skill-abundant closed economy is reflected in a lower relative price index for the skill-intensive good: $P_{1}^{H} / P_{2}^{H}<P_{1}^{F} / P_{2}^{F}$. Under costly trade, from equation (29), the relative price indices may be expressed as:

$$
\frac{P_{1}^{k}}{P_{2}^{k}}=\left[\frac{M_{1}^{k}\left(p_{1 d}^{k}\left(\widetilde{\varphi}_{1}^{k}\right)\right)^{1-\sigma}+\chi_{1}^{j} M_{1}^{j}\left(\tau_{1} p_{1 d}^{j}\left(\widetilde{\varphi}_{1 x}^{j}\right)\right)^{1-\sigma}}{M_{2}^{k}\left(p_{2 d}^{k}\left(\widetilde{\varphi}_{2}^{k}\right)\right)^{1-\sigma}+\chi_{2}^{j} M_{2}^{j}\left(\tau_{2} p_{2 d}^{j}\left(\widetilde{\varphi}_{2 x}^{j}\right)\right)^{1-\sigma}}\right]^{1 /(1-\sigma)},
$$


for $k, j \in\{H, F\}, j \neq k$. As $\tau_{i} \rightarrow \infty$ and $f_{i x} \rightarrow \infty$ for $i \in\{1,2\}$, the costly trade relative price index converges to its autarkic value. In equation (62), $\chi_{i}^{k} \rightarrow 0$, while $M_{i}^{k}$ and $p_{1 d}^{k}\left(\widetilde{\varphi}_{1}^{k}\right)$ converge to their autarky values.

As $\tau_{i} \rightarrow 1$ and $f_{i x} \rightarrow 0$ for $i \in\{1,2\}$, the costly trade relative price index converges to its common free trade value. In equation $(62), \chi_{i}^{k} \rightarrow 1$, while $M_{i}^{k}, p_{i d}^{k}\left(\widetilde{\varphi}_{i}^{k}\right)$ and $p_{i d}^{k}\left(\widetilde{\varphi}_{i x}^{k}\right)$ converge to their free trade values, where $p_{i d}^{k}\left(\widetilde{\varphi}_{i}^{k}\right)=p_{i d}^{k}\left(\widetilde{\varphi}_{i x}^{k}\right)=p_{i d}^{j}\left(\widetilde{\varphi}_{i}^{j}\right)=p_{i d}^{j}\left(\widetilde{\varphi}_{i x}^{j}\right)$.

For intermediate fixed and variable trade costs where selection into export markets occurs, the relative price indices will lie in between the two countries' autarky values and the common free trade value: $P_{1}^{H} / P_{2}^{H}<P_{1}^{F} / P_{2}^{F}$.

In the absence of cross-industry differences in $\tau_{i}$ or $f_{i x} / f_{i}$, this difference in relative prices indices implies, from equation (31), that $\Lambda_{i}^{k}$ will be smaller in a country's comparative advantage industry than in the country's comparative disadvantage industry $\left(\Lambda_{1}^{H}<\Lambda_{2}^{H}\right.$ and $\left.\Lambda_{2}^{F}<\Lambda_{1}^{F}\right)$.

From the proof of Proposition 6, the industry with the smaller value of $\Lambda_{i}^{k}$, and hence the larger increase in the expected value of entry following the opening of costly trade, must experience a larger increase in $\varphi_{i}^{* k}$ in order for $V_{i}^{k}$ to equal the sunk entry cost $f_{e i}$.

(b) The larger increase in the zero profit productivity cutoff, $\varphi_{i}^{* k}$, in the country's comparative advantage industry will result in a larger increase in weighted average productivity, $\widetilde{\varphi}_{i}^{k}$, in the comparative advantage industry. Since this is true for both countries, the opening of costly trade will result in the emergence of endogenous Ricardian productivity differences at the industry level, which are positively correlated with Heckscher-Ohlin-based comparative advantage $\left(\widetilde{\varphi}_{1}^{H} / \widetilde{\varphi}_{2}^{H}>\widetilde{\varphi}_{1}^{F} / \widetilde{\varphi}_{2}^{F}\right)$.

(c) Since $\Lambda_{i}^{k}$ is smaller in a country's comparative advantage industry than in the comparative disadvantage industry, and the probability of exporting, $\chi_{i}^{k}=\left[1-G\left(\Lambda_{i}^{k} \varphi_{i}^{* k}\right)\right] /[1-$ $G\left(\varphi_{i}^{* k}\right)$ ], is monotonically decreasing in $\Lambda_{i}^{k}$, it follows immediately that the probability of exporting will be greater in a country's comparative advantage industry, which establishes the proposition.

\section{A8. Numerical Solutions}

We consider a symmetric reduction in the variable costs of trade from $\tau=2$ to $\tau=1.2$. Following the empirical results using plant-level data in Bernard, Eaton, Jenson and Kortum (BEJK, 2003), we set the elasticity of substitution $\sigma=3.8$. BEJK (2003) find that the standard deviation of log US plant sales is 1.67, and because the standard deviation of log sales in the model is $1 /(a-\sigma+1)$, we set the Pareto shape parameter $a=3.4$, which 
satisfies the requirement for the standard deviation of $\log$ firm sales to be finite, $a>\sigma-1$.

We choose symmetric values for country factor endowments $\left\{\bar{S}^{H}=1200, \bar{L}^{H}=1000, \bar{S}^{F}=\right.$ $\left.1000, \bar{L}^{F}=1200\right\}$, industry factor intensities $\left\{\beta_{1}=0.6, \beta_{2}=0.4\right\}$, and the share of the two goods in consumer expenditure $\left(\alpha_{1}=\alpha=0.5\right)$. Changing the fixed cost of entry, $f_{e i}$, rescales the mass of firms in an industry and, without loss of generality, we set $f_{e i}=f_{e}=2$. We set the minimum value for productivity $k=0.2$.

Fixed production costs are set equal to $5 \%$ of fixed entry costs, $f=f_{i}=0.1$, and as a convenient normalization fixed exporting costs are set equal to fixed production costs, $f_{x}=f_{i x}=f$. Exit in the model includes both the endogenous decision of firms with low productivity draws to leave the industry and exogenous death due to force majeure events. Changes in the probability of exogenous firm death, $\delta$, rescale the mass of entrants relative to the mass of firms and, without loss of generality, we set $\delta=0.025$. 


\begin{tabular}{|c|c|c|c|c|}
\hline & $\begin{array}{l}\text { Comparative } \\
\text { Job Turnover }\end{array}$ & $\begin{array}{l}\text { ntage Industry } \\
\text { Decline From } \\
\text { Autarky to } 20 \%\end{array}$ & $\begin{array}{l}\text { Comparative D } \\
\text { Job Turnover }\end{array}$ & $\begin{array}{l}\text { antage Industry } \\
\text { Decline From } \\
\text { Autarky to } 20 \%\end{array}$ \\
\hline \multirow{3}{*}{ 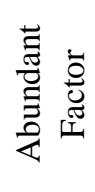 } & Total & 20.7 & Total & 14.3 \\
\hline & Between-Industry & 7.3 & Between-Industry & -7.3 \\
\hline & Within-Industry & 13.3 & Within-Industry & 7.0 \\
\hline \multirow{3}{*}{$\begin{array}{l}\tilde{0} \\
\tilde{U} \\
\tilde{T} \\
\tilde{U} \\
\tilde{U} \\
\tilde{D} \\
\tilde{n}\end{array}$} & Total & 15.6 & Total & 20.1 \\
\hline & Between-Industry & 6.9 & Between-Industry & -6.9 \\
\hline & Within-Industry & 8.7 & Within-Industry & 13.2 \\
\hline
\end{tabular}

Notes: Table displays jobs added and lost as a percent of countries' total labor force in response to noted decline in variable trade costs. Between-industry (i.e. net) job turnover refers to the net number of jobs added to $\left(^{+}\right)$or lost from (-) an industry. Within-industry turnover refers to jobs added and lost in the same industry. Total (i.e. gross) job turnover is the sum of the absolute value of the between- and within-industry components. Note that one worker changing jobs results in one job loss and one job gain. As a result, the share of the labor force changing jobs is half the sum of the total turnovers noted in the table.

Table 1: Job Turnover as Trade Costs Fall 


$\underbrace{1}_{\text {Exit }} \varphi_{i}^{*} \underbrace{1}_{\begin{array}{c}\text { Produce for domestic } \\ \text { market only }\end{array}} \varphi_{i x}^{*} \underbrace{\underbrace{*}}_{\begin{array}{c}\text { Produce for domestic } \\ \text { and foreign market }\end{array}} \in(0, \infty)$

Figure 1: Zero-profit and exporting productivity cutoffs with costly trade 

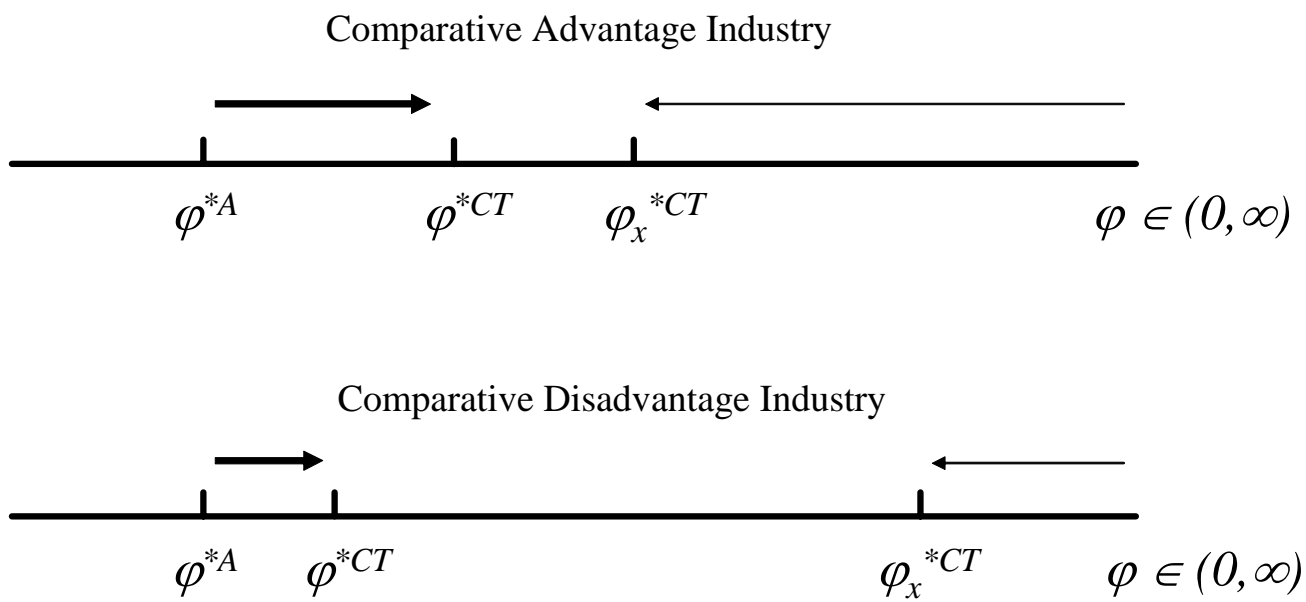

$\mathrm{A}=$ autarky $\mathrm{CT}=$ costly trade

Figure 2: From autarky to costly trade: differential movements of the productivity cutoffs across industries 

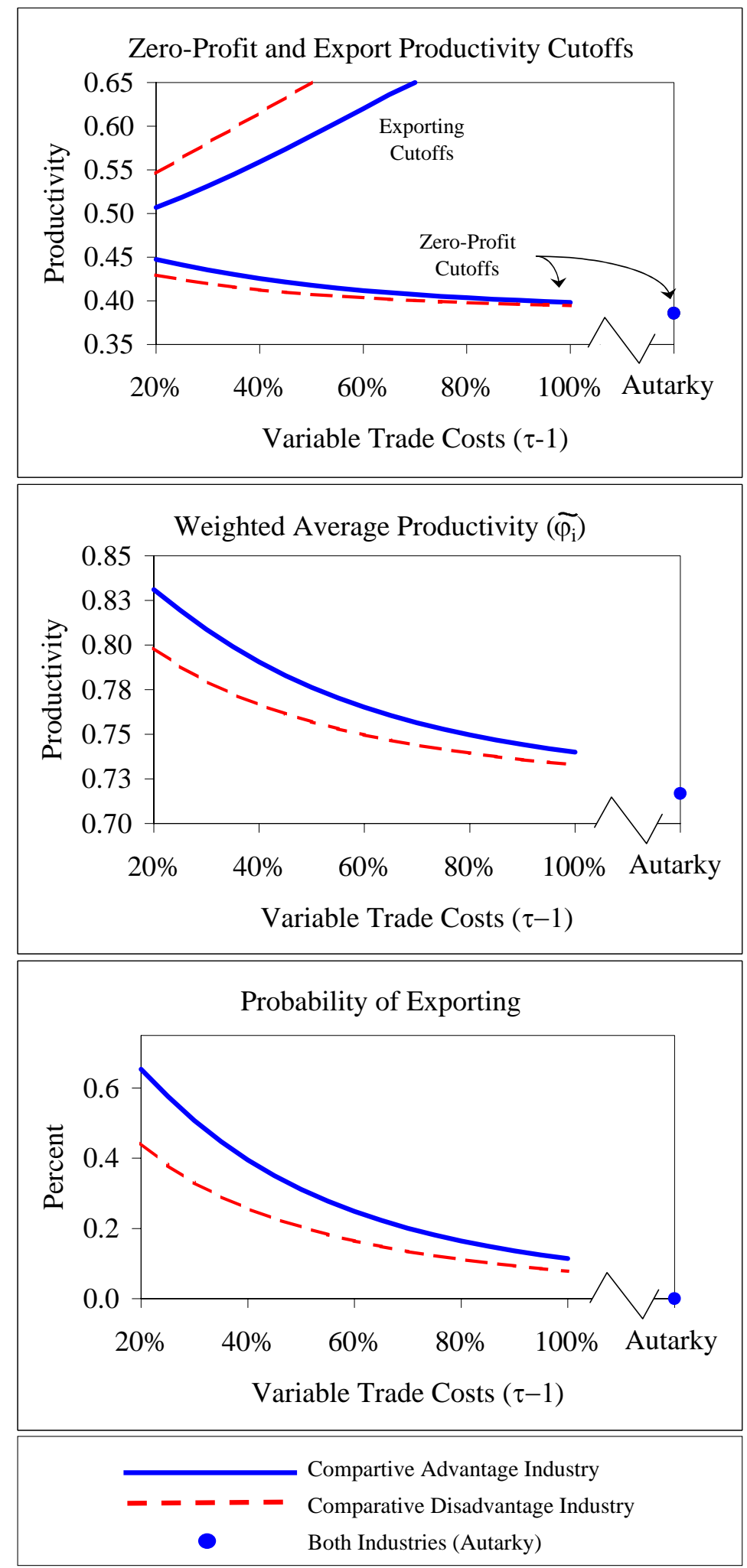

Figure 3: Productivity Cutoffs, Average Productivity and Probability of Exporting as Trade Costs Fall 

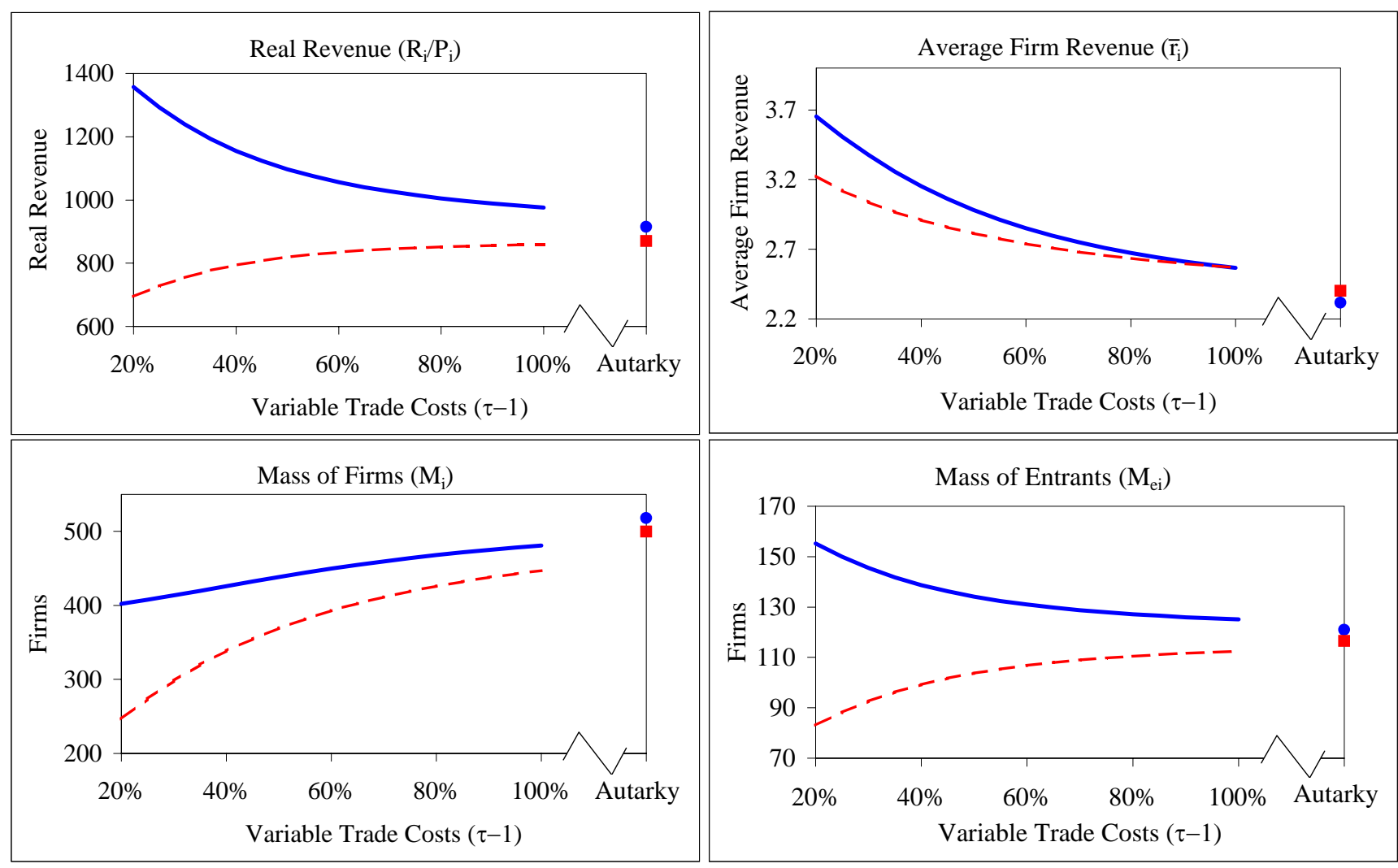

\section{Compartive Advantage Industry}

(Autarky Value)
- - - - - · Comparative Disadvantage Industry
(Autarky Value)

Figure 4: Properties of the Costly Trade Equilibrium 

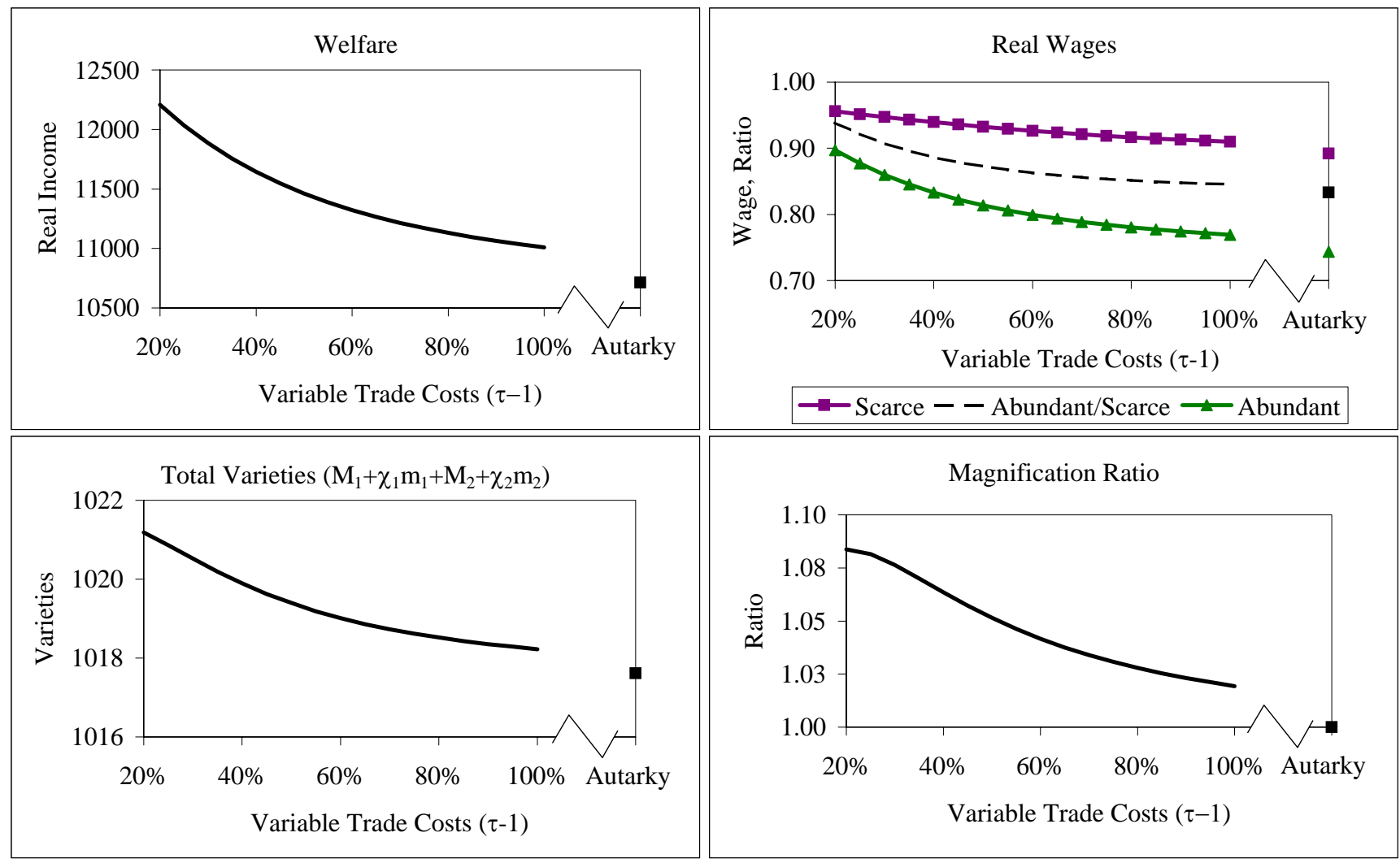

Note: Endogenous productivity differential is the ratio of Home versus Foreign average industry productivity in the comparative advantage industry to the same relative quantity for the comparative disadvantage industry. See text for formal definition.

Figure 5: Welfare and Its Components 

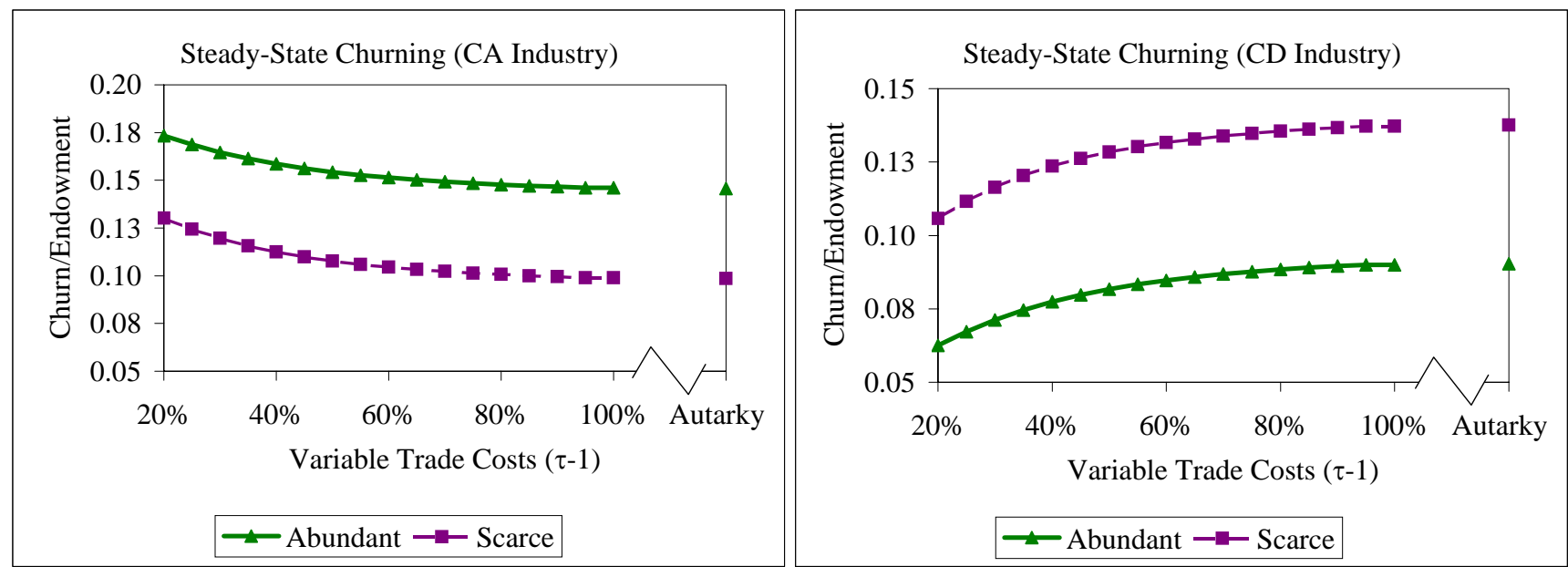

Note: Factors employed in steady-state churning are those used for entry and by exiting firms.

Figure 6: Steady State Employment Churning 